\title{
In Search Of The Qualitative Clear Majority: DEMOCRATIC EXPERIMENTALISM AND THE QUEBEC SECESSION REFERENCE
}

\author{
CRISTIE L. FORD
}

This article attempts to marry direct democratic deliberation with the enforcement of important constitutional norms in the context of a real-life policy question.

The question is the secession of Quebec. The author argues that a referendum is netther the most legitimate nor the most effective way to address the issue. The debate over Quebec's future needs to be reoriented by reference to the broad normative framework set out by the Supreme Court of Canada in the Secession Reference, combined with a renewed democratic process. The author introduces an innovative non-Canadian constitutional model called "democratic experimentalism," which seeks to ensure legitimacy, participation, and accountability within heterogeneous, complex democratic systems as a fresh perspective on Canada's troubled federalism debate.

The author concludes that democratic experimentalism is compatible with Canada's constitutional values and traditions, and with the standard of the "clear qualitative majority" vote set down by the Supreme Court of Canada. Equally, the Secession Reference approach contains within it an important new understanding of how pluralist democracies globally should approach fundamental constitutional questions.
Cet article essaie de marier une délibération démocratique directe et l'application de normes constitutionnelles importantes dans le contexte d'une question de politique pratique.

La question est la sécession du Québec. L'auteur prétend qu'un référendum ne représente ni la façon la plus légitime ni la plus efficace de régler la question. Le débat sur l'avenir du Québec doit être réorienté en fonction du large cadre normatif établi par la Cour suprème du Canada dans son document intitulé Secession Reference, alliè à un processus démocratique renouvelé. $L$ 'auteur présente un modèle constitutionnel non canadien novateur appelé aexpérimentalisme démocratique" qui cherche à assurer la légitimité, la participation et la responsabilité au sein de systèmes démocratiques, complexes et hétérogènes avec une perspective nouvelle du débat chaud sur le fédéralisme canadien.

$L$ 'auteur conclut que l'expérimentalisme démocratique est compatible avec les valeurs et traditions constitutionnelles du Canada ainsi qu'avec la norme de vote à "la majorité qualitative claire" établi par la Cour suprême du Canada. De même, la démarche de Secession Reference comporte une importante nouvelle compréhension de la démarche que les démocraties pluralistes devraient adopter globalementà l'égard des questions constitutionnelles fondamentales.

\section{TABLE OF CONTENTS}

I. A BLUE-SKY STORY $\ldots \ldots \ldots \ldots \ldots \ldots \ldots \ldots \ldots \ldots \ldots 12$





A. LOOKING BEYOND PUbLIC SECTOR REFORMS . . . . . . . . 519

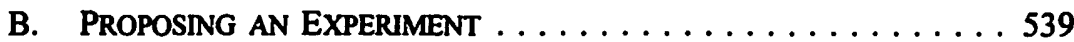

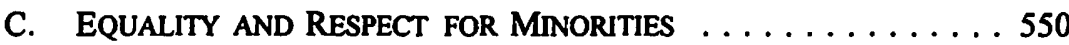

IV. Conclusion: The Qualitative Clear Majority ....... 558

B.A., University of Alberta; LL.B. University of Victoria; LL.M., Columbia University. Attomey, Davis Polk \& Wardwell, New York, and 2000-2001 Lecturer in Law, Columbia University School of Law. I produced an earlier version of this article while studying at Columbia, and a number of people have contributed to its development. The author is particularly grateful to James Liebman, Charles Sabel, and Mark Tushnet for their exceptionally helpful comments. 


\section{A BLUE-SKY STORY}

Picture this: the second most populous region in an affluent federal democracy is thinking about seceding from the rest of that country. The regional government has held two referendums on secession in the span of a generation. In both cases the results were very close, and the population remains divided on this emotional issue. An appeal is taken to the highest federal court on the question of what would be required for the region to secede legally under the federation's constitution, but the court's reply does not rein in the debate. The court talks about the traditions of the country and the way such decisions are made. It sets out the country's four deepest constitutional values: democracy, federalism, constitutionalism and the rule of law, and respect for minorities. It answers, quite simply, that any region that wants to leave the federation must honour these values and must demonstrate that a "qualitative" and "clear" majority of its people actually want to secede. Then, the court throws the question back to the political arena. Years pass while the federal and regional governments stake out their positions through strategic statutes, all the while trying to get on with the daily business of government. Existing political solutions seem too pumy to tackle the task. Faith in elected political representatives reaches a deep low. Citizens grow ever more disenchanted, and they withdraw from even trying to resolve a dilemma that seems so complicated and impossible. Uneasy silence falls.

In a decentralizedand globalizing world, discontented minorities within a single nationstate, often with longstanding grievances and a historical sense of nationhood, are not uncommon. The questions they face are hard ones that go to the very roots of their identities. This region is no exception. It has long been performing a difficult three-part balancing act between the need to ensure the survival of its own distinct culture in a the midst of a different surrounding cultural and linguistic environment; the need to protect its economic and social well-being in an increasingly interconnected global community; and the need to recognize and respect its own internal diversity. In many respects, its internal struggle over secession is only part of a larger social uncertainty over how the region sees itself and where it wants to go. Thus the issue refuses to fade away, in spite of the population's weariness.

Then comes the change: this region's people - incrementally at first, and then in a more conscious and organized fashion - take matters into their own hands. Their starting point is that the options put before them by the political system are unsatisfactory neither total separation nor the status quo will heal the divisions they are so keenly aware of in their own communities. Drawing on their own experiences, local groups begin to talk about their region's relationship to the rest of the country in a fresh way, looking at the assumptions they have about what is possible and challenging the rigid options that their governments - regional and federal - have set before them. They talk about foreign relations, the national debt, Aboriginal peoples, the environment. They talk about the elements set out in the Secession Reference - the four pillars of national constitutional tradition that describe what it would take for the region to secede legally from the enveloping state. They talk about federalism, secession, globalization, history, and the future. 
The groups face great challenges and frustrations along the way and many of them dissipate. Faced with the lack of other alternatives, however, and tired of the chronic lowlevel dysfunction in their own communities, some return to the table to brainstorm about how to make their deliberations work. They look at the process they are engaged in, reflecting on the successes and challenges of getting people to agree and to stay involved. Individuals in the community with experience in conflict resolution and strategic planning are drawn in. They identify stakeholders, key players, issues and concerns, and they set timelines. They develop a strategic plan and set goals for themselves. This time, rather than focusing on large theoretical questions about governance, the groups try to look at concrete examples of how the sovereignty debate and its attendant policies - in education, immigration, language rights, business regulation - affect interactions in their own community. As the discussion proceeds, it becomes unavoidably obvious that questions about language, identity, and culture cannot be contained within the abstract world of formal politics; in complicated and immediate ways, they spill over into the personal, cognitive, social, economic, and local realms. New stakeholders emerge and the community seems more diverse than ever. Simply because they have no choice, the discussion groups proceed in small, knowable steps.

Somewhat unexpectedly, progress is made. Participants - even those from very different perspectives - find that they can agree on quite a lot when they break things down into concrete issues, draw on their own experiences, listen carefully to others' perspectives, and challenge rigid either/or presentations. By chipping away at problem areas, new and unanticipated bands of agreement between groups are located, which in turn suggest new avenues of exploration. Thorny issues are approached from different angles. The groups learn that having a diversity of perspectives represented in their discussions demonstrably improves outcomes (in terms of reaching workable accommodations) because it enlarges the range of options on the table and opens up new ways of thinking about old stalemates. Partly in response to that discovery and partly out of a sense of fairness, they try to ensure that all the interests in their communities have a place at the table. Yet it also becomes clear that existing identifiable groups in the neighborhood (the business community, cultural minorities, the linguistic majority, the unemployed) are not at all monolithic, and they cannot be represented in essentialist, collective terms on every issue. The groups find that hiving social or personal issues from political ones is both unrealistic and counterproductive in an interconnected local community, and they struggle to manage as much as they can. They discover that the very act of respectful, open-minded conversation has value in itself as a means of building social agreement. And they discover that their own experience, rather than deference to others' authority or expertise, is the best guide to building agreement in their own community. Some groups track their successes, and some cynics begin to keep half an eye on the goings-on.

Local groups start to talk to each other. They pool information and compare notes on their substantive agreements and on processes that led to success in breaking stalemates and keeping the process functioning. In spite of the range of individual issues on their tables, the groups identify some common reference points and comparable experiences. An Internet library and "clearing house" develops. It starts to maintain a database of the groups' experiences with resolving disputes, managing participation, representing 
different community interests, and planning strategically. It disseminates success stories and publicly recognizes breakthroughs in negotiations. People even become curious about the experiences of other nations in managing diversity and democracy, to be used as raw material for sifting through the discursive process. High-performing localities draw on this aggregate information to improve their own processes and further their own deliberations.

Somewhere along the way, to everyone's surprise, it starts to look as though this network of piecemeal local experiments may aggregate into something noteworthy. A snapshot of the public mood emerges - grainy, but promising. The region's citizens begin to identify degrees of agreement on aspects of a new arrangement with the rest of the country. Blunter instruments for measuring public opinion - yes/no referendums, single issue election votes - appear divisive and unsatisfactory by comparison. Wild-eyed optimists even speculate about the possibility of creating a more participatory and legitimate form of democratic governance based on the local experiments.

It is at this point that people need to get serious: they need to move from feel-good but relatively ineffective and disjointed community-based deliberations to something more rigorous. A second crucial event occurs - a crisis of some kind, perhaps - and suddenly it is obvious that the region needs to get on with the business of its future and take some truly meaningful steps toward change.

Drawing on lessons learned in the country's public sector over the last ten years, the Internet clearing house starts to monitor the local groups and compare their success in terms of the quality of their process. It develops general procedural guidelines to ensure that the local bodies use strategic planning tools, observe and develop "rolling" best practices standards for participation and decision making, and maintain essential informational resources. A preliminary "Members' Code of Conduct" is drafted to entrench the values of transparency, accountability, accessibility and broad participation, and respectful dialogue in the local debates. As a crucial element of good procedure, groups are required to give reasons for their decisions. The clearing house starts to challenge groups to meet benchmarks set by the most successful, to be accountable for their own process, and to learn from their own and others' experiences. Learning becomes systematized. In light of the unequal distribution of resources and expertise in different areas of the region, the clearing house starts to consider providing capacity-building resources to struggling regions. Information is managed in increasingly comprehensive and nuanced ways. As the local groups digest and reflect upon this body of knowledge, they in turn cause the centre to reformulate its own goalposts and refine its own conclusions. The clearing house learns that technical expertise and a good, accessible resource library, while indispensable, is no substitute for inclusive local deliberations in terms of reaching consensus and creating appropriate new possibilities.

At the same time, people recognize that even the most perfect public deliberative process is incomplete and fragile without some sense of the social ends toward which it is directed. They return to the four pillars of the national constitutional tradition federalism, democracy, constitutionalism and the rule of law, and respect for minorities - and they begin to think in earnest about the meaning of a "qualitative clear majority" on the question of the region's future relationship with the rest of the country. The local 
groups - more responsive, more accessible, possessed of greater contextual intelligence than the centre is - retain their autonomy to the extent that they follow "good practices" in participation, accountability, fairness, and respectful deliberation. Those that demonstrate their use of good participatory practices and adherence to national constitutional values are given, in return, a great deal of leeway in their experiments.

In small steps, as always, the groups begin to venture into the supremely difficult territory between constitutionalism and democracy, between fairness and efficiency. They experiment with ways to measure "voice." They struggle to balance individual and group interests. Repeatedly, they confront deep normative disagreements and closely held convictions. With the benefit of compounded learning from multiple local experiments, all the imaginative resources of the region's diverse society are plowed back into the process of developing considered, creative new options for a satisfactory collective future. Slowly, new possibilities emerge from the give-and-take. Entrenched antagonisms give way to shifting, overlapping coalitions and novel accommodations - contingent always, issuespecific, pragmatic and discrete - and by an accretion of small agreements, even the questions refine and reformulate themselves. What is more, it occurs through a democratic process that is more broadly and deeply participatory, more transparent and accountable, and more demonstrably successful at achieving social consensus than anything that has come before it.

The change takes everyone - the region, the rest of the country, the rest of the world - by surprise. Something that started as a pragmatic experiment without grand pretensions has become a new form of flexible, directly deliberative democracy.

\section{INTRODUCTION}

The story of Quebec's stormy relationship with the rest of Canada is dully familiar: the last twenty years have seen two secession referendums, two failed attempts to amend the Canadian constitution, countless public opinion surveys and one constitutional reference on the precise issue of whether it is possible for Quebec to secede legally from the rest of the country.' Nevertheless, the balance of this article suggests that the Blue-Sky Story above is not as unfamiliar or as impossible as it may seem at first blush. New ways of looking at governance have emerged in recent years, which have broad implications for democracy, and which can change the range of options available to societies in thinking about and implementing their deepest constitutional values. Moreover, these new constitutional theories have their roots in some rather innocent-looking, garden variety trends toward community-based decision making and governmental accountability that already exist in practice, in Canada and elsewhere. Taken together with Canada's own constitutional traditions, they make it possible to imagine a procedural and conceptual framework for Quebec's ongoing secession debate that is more successful, more legitimate, and more deeply democratic than the ones currently in place.

The argument that follows proceeds from the position that the terms of the current political debate are obscuring the real issues and artificially limiting the possibilities 
available to Quebecers and Canadians. My starting point is the potentially controversial one that, given the sharp divisions in Quebec society, the best way to answer the secession question is not by way of a simple referendum. Referendums are attractive for their directly democratic quality. However, they provide adequate, legitimate answers to fundamental social questions only where substantial social agreement on those underlying questions already exists. They cannot build consensus, and they ought not to be used to paper over differences of opinion or to justify enforcing the political will of a majority where there is significant disagreement. This is the current situation in Quebec: the near equal split between sovereigntists and federalists on the last referendum caused a political impasse, and, more fundamentally, it indicated a crisis of political method with which a traditional political mechanism like the referendum was never designed to cope. ${ }^{2}$

The process described here is also significantly different from the customary calls for public consultation or for the establishment of a Royal Commission to study the problem. ${ }^{3}$ It differs from proposals for reforming the electoral system, ${ }^{4}$ for example, because it contemplates a new form of direct democracy rather than modifications to existing structures of representative democracy. Morreover, it goes well beyond the public input processes that have already been tried. ${ }^{5}$ While earlier initiatives sought to capture an accurate "snapshot" of public opinion on constitutional change, none of them to date have attempted to turn that public input into a broad-based dialogue capable of moving the debate systematically forward.

I suggest a way to reorient this debate by reference to the "rules of the game" set out in August 1998 when the Supreme Court of Canada addressed the question of what would be required for Quebec to secede unilaterally from Canada under Canadian constitutional

Historian Michael lgnatieff takes an even dimmer view of using a referendum to negotiate treaties with the First Nations in British Columbia, as that province's new Liberal government has proposed. In an interview with the Vancouver Sun Ignatieff suggest that such a referendum would "damage the identity of the province" and likely "institutionalize majority tyranny": D. Beers, "Treaty referendum: 'way of chaos"' Vancouver Sun (3 May 2001) Al0.

The Royal Commission is a relatively common institution in Canada, by which the federal government appoints a task force of high profile experts to consider a timely issue and make recommendations for action. While Royal Commissions generally produce well-researched and wellconsidered reports by qualified individuals, those reports often take several months or even years to complete. Alongside the informational mandate, governments have historically used Royal Commissions as a device to channel or defer debate on, and periodically to gloss over, difficult political issues.

An interesting recent proposal is H. Maclvor, "Proportional and Semi-Proportional Electoral Systems: Their Potential Effects on Canadian Politics" (Presented to the Advisory Committee of Registered Political Parties, Elections Canada, Ottawa 23 April 1999), online: Elections Canada Homepage <http://www.elections.ca/news/research/review_e.html> (date accessed: 19 April 2000).

Two examples from 1991 are Quebec's Belanger-Campeau Commission and the federal Spicer Commission and Beaudoin-Edwards Committees. A short history of these initiatives, produced by a non-profit organization called uni.ca, is available online: uni.ca <http://www.uni.ca> (date accessed: 19 April 2000) [hereinafter "uni.ca"]. Uni.ca also hosts the link to an ongoing effort to foster dialogue among Canadians about the country's future: Dialogue Canada, online: <http://www. uni.ca/dialoguecanada> (date accessed: 19 April 2000). In August 2001 I joined the Board of Directors of uni.ca, but I would like to emphasize that the views expressed here are entirely my own and do not necessarily reflect the views of that organization or of any of its other board members. 
law. ${ }^{6}$ In the Secession Reference the Court established the hurdle that Quebec must overcome in order to secede legally (that is, constitutionally) from Canada: Quebec must achieve a clear, qualitative majority vote on a clear referendum question in favour of secession. My point is that this standard - the qualitative and legitimate majority on a clearly defined and fundamental question - represents an important new understanding of how pluralist democracies should be approaching constitutional decision making. Moreover, the new goal requires a fresh perspective on Canadian federalism and a new kind of democratic process. ${ }^{\text {? }}$

The argument proceeds in three stages. It begins with a thumbnail sketch of trends in what is variously called "new public management" or "regulatory reform" in the Westminster parliamentary systems. I then touch on the Canadian experience with administrative and regulatory reform and with employing community-based decisionmaking tools in a range of public and semi-public forums. The pattern seems to be that, while certain initiatives are promising in terms of taking seriously broad intersectoral community involvement in public decision making, the "missing link" that prevents them from being viable new forms of governance is accountability. From this point, I move to consider an American constitutional law theory that addresses this concern and proposes new possibilities for managing participation and achieving effective levels of consensus in heterogeneous, complex political systems. The highly original model, developed by Michael Dorf and Charles Sabel, ${ }^{8}$ traces its roots to contemporary organizational theory as well as, on the philosophical plane, to civic republicanism, pragmatism, and radical democracy theory. Dorf and Sabel extrapolate from the developments taking place in public management in Canada and elsewhere to challenging but logical ends, with significant implications for federalism, rights discourse, and the role of the courts in constitutional democracies. I argue that the participatory, flexible, and accountable processes inherent in democratic experimentalism can contribute to the quality of public debate in Quebecois society on the issue of secession.

The next part introduces the situation in Quebec and reviews the Secession Reference. In constructing the Secession Reference as it did, the Supreme Court of Canada (certainly without conscious awareness of the theory itself, though perhaps influenced by underlying developments in Canadian public management) is operating much like the democratic experimentalist court Dorf and Sabel describe. It sets out only the broad normative framework within which democratic constitutional deliberation is to take place - that is, the four pillars of the Canadian constitutional tradition: democracy, federalism, constitutionalism and the rule of law, and respect for minorities - and leaves the resolution of the details to the political process. As well, the Court's method seeks to ensure that the democratic process is operating legitimately and with due regard for the

Reference Re Secession of Quebec, [1998] 2 S.C.R. 217 [hereinafter Secession Reference]. It should become clear through the course of this article that nothing contained here amounts to a personal endorsement of dismantling Canadian federalism or complete Quebecois secession. On the contrary, for reasons I hope to have articulated below, I remain convinced that federalism is the most promising alternative for all of Canada, including Quebec.

C. Sabel \& M. Dorf, "A Constitution of Democratic Experimentalism" (1998) 98 Colum. L. Rev. 267 [hereinafter "DE"]. A more recent version of the article will soon be published as a book (Harvard University Press, forthcoming in 2001). 
participation interests of social groups by establishing a network of procedural expectations analogous to the "rolling best practices standards" described by Dorf and Sabel. As is appropriate in serious constitutional discourse, the Court allocates political and judicial roles in a way that balances democratic pressures with the protective mechanisms that constitutional rights require in any pluralistic and unequal society.

Finally, the article considers whether the fluid, decentralized constitutional model proposed by Dorf and Sabel is capable of coexisting, at an essential level, with Canada's unique experiences with managing a culturally and linguistically pluralist democracy. I sketch out the relationship between Canada's historical experiences, its sophisticated national scholarship on multicultural citizenship and identity, and the assumptions behind the Secession Reference. I reach the conclusion that democratic experimentalist methods can be sensitive to the Canadian tradition of granting explicit recognition to minority groups, as well as individuals, and conversely, there is nothing in the Secession Reference that would contraindicate applying a DE-style fluid deliberative model. On the contrary, the model may hold out substantial promise as a way of managing the tension between unity and diversity in Canada. Moreover, the understanding of constitutional federalism that emerges in the Secession Reference is an important contribution to democratic experimentalism itself. I conclude with some observations about the meaning and importance of the notion of the "clear qualitative majority" developed by the Supreme Court of Canada.

This article represents a preliminary and ambitious weaving together of a new constitutional theory, the animating principles of Canadian constitutionalism, and some trends in public decision making that have been operating in Canada for some time. There is enormous and exciting further work to be done. Moreover, any imagined approach to a pragmatic public decision-making experiment like this one can only be a starting point, one of limited value outside the field of real human interaction. Nevertheless, enough synergies exist between these three trends that each side of the conversation stands to be enriched: Canada stands to enrich its troubled federalism debate (as well as its public management practices) by considering new imaginative possibilities. In return, the Canadian perspective on cultural pluralism makes a unique and important contribution to the emerging transnational scholarship on new forms of governance. ${ }^{9}$ The opportunities for stimulating debate alone make the exercise worthwhile.

9 Other models of governance exist in Tony Blair's so-called "Third Way" in the United Kingdom, his approach to the conflict in Northern Ireland, and emerging versions of federalism and parliamentarism in Northern Ireland. Further comparative study is warranted on the commonalities and divergences between American democratic experimentalism, Canadian perspectives on federalism and governance, and various related conversations taking place in Europe on the subject of "network governance." See for example infra note 37. 


\section{DEMOCRATIC EXPERIMENTALISM IN CANADA}

\section{A. Looking Beyond Public Sector Reforms}

\section{PUBLIC SECTOR REFORM IN WESTMINSTER}

This discussion must begin with a description of some fundamental changes in public management theory that have taken place over the last two decades. The model employed below is an American one, and Canadians in particular may tend to associate certain of its characteristics - the incorporation of lessons from private sector management theory into public governance; the delegation of seemingly public regulatory duties to private actors - with a distinctly American style of governance within which the public sector plays a comparatively less central role in society. Even within the United States these models are sometimes linked conceptually with "conservative" trends toward devolving responsibility for social programs to the state level, relying on voluntary compliance codes for industry, and generally pulling away from more activist governmental models. In fact, this is not accurate: the model is an integral part of contemporary Westminster public administration. Moreover, while the new regulatory (or "new public management") model was developed as a tool for enforcing restraint on government, its demonstrated value in improving regulatory efficiency and effectiveness has led to its adoption by governments across the political spectrum. ${ }^{10}$

According to Peter Aucoin's comparative study of governance in the Westminster systems of Great Britain, Australia, New Zealand, and Canada, this "revolution in public management" first arose during Margaret Thatcher's tenure in Britain as part of a larger economic and political program of enforcing restraint on government. In the 1980s the new approach came to be adopted by political parties across the political spectrum, including Labour governments in Australia and New Zealand. In each of the Westminster systems, elected officials had come to believe that the professional bureaucracy had acquired too much control over the management of the state, that bureaucratic organizational design had become too restrictive of both bureaucrats and elected officials, and that the bureaucracy had become pathologically observant of rigid rules and procedures. Pressure on government to achieve better results came from three sources common to all Western democracies at the time: the political and economic need to reduce public spending, the widespread decline of public confidence in the effectiveness and quality of public programs, and the need for nation-states to compete in a new, global economic order. " Efforts were made to emphasize performance and measurable results, to break up ossified institutional structures, and to prioritize responsiveness. The result was a new public management ethic that consolidated authority for developing high-level strategic priorities and strict budgetary restrictions at the centre of government, while devolving operations and implementation to dedicated departments and private stakeholders on the basis of incremental efficiency assessments. In effect, this meant that argued analysis of the reform efforts within Great Britain, Australia, New Zealand, and Canada. 
standard-setting, monitoring, and other aspects of policy implementation were developed in concert with private industry, outside contractors, and other non-governmental stakeholders. ${ }^{12}$ Along with decentralization, the model consciously borrowed other effective private sector management strategies, such as performance and outcome measures (including targeting and benchmarking), best practices comparisons, and steps to augment the flexibility, cost-effectiveness, and "corporatization" of the public service. On a deeper level, the new model was also a response to conceptual questions about the legitimacy of the modern administrative state. ${ }^{13}$

Particularly in New Zealand, where the new managerialism was influenced by a coherent application of public choice theory and organizational economic theory (including agency and transaction cost economic models) ${ }^{14}$ and adjusted pragmatically for Westminster political and constitutional traditions, ${ }^{15}$ the reforms were sweeping. The experiment in New Zealand was exceptional in its ambition, its coherence, the novel ways in which theoretical and practical influences were integrated, and its success: in 1993 the World Economic Forum ranked New Zealand first for the quality of its government. ${ }^{16}$

12 Devolving standard-setting tasks to industry is a significant move from a govemance perspective, and it has attracted important comment in Europe, see infra note 37.

13 The challenge raised to the administrative state in parliamentary systems arose out of deep cynicism about the accountability and impartiality of the professional civil service. The modern Westminster model of govermment rests on two pillars: responsible government and the professional public service. The principle of responsible government means that elected politicians must assume complete responsibility for all actions taken by the bureaucracy under their management. Politicians are expected to resign their posts should serious errors or scandals emerge from their ministry, whether or not they were involved in the problem or even had actual knowledge of it. The principle of the professional public service envisions a cadre of long serving career bureaucrats chosen on the basis of merit and held to high ethical standards. Because they are accountable to the elected representative in the event of incompetence or improper execution of their function, and because their careers outlive any one government's tenure, their interests lie in loyal, competent, and non-partisan service of the elected representative's policies. Thus the accountability of the public service is entirely internal to the government department. The intellectual challenge to the idea of a career public service came from public choice theory, augmented in the context of the closed character of the administrative state. The resulting image, particularly in the United Kingdom and Canada, was of a self-serving, unaccountable, budget-maximizing and bloated public bureaucracy. Over the past five years the Westminster systems may have halted the trend toward politicization of their bureaucracies and reaffirmed the value of the independent, professional civil service as part of the "new public management approach": The New Public Management, supra note 10 at 25-34, 49-82. A careful assessment of the effect of new public management theory on responsible government and the professional public service in New Zealand appears in J. Boston et al., Public Management: The New Zealand Model (Auckland, NY: Oxford University Press, 1996) at 316-47 [hereinafter The New Zealand Model]. The modem administrative state has also been under attack in the United States, of course, though for different reasons. The New Zealand Model, ibid. at 16-40.

is Ibid. at 42-68, 333-47. A few key aspects of the framework of government in New Zealand are its unitary (i.e., non-federal) structure; its parliamentary (i.e., "Westminster") and "responsible" form of government; the exceptional historical dominance of the executive branch under a series of singleparty majority governments; its firmly established state-owned enterprises and cadre of career public servants; and its Whitehall-derived constibutional conventions and common law tradition of judicial review, supplemented by statutes including a Bill of Rights Act. See generally The New Zealand Model. 
Crucially, the Labour government that initiated the reforms did so in concert, not with "downloading" of public responsibilities to the voluntary/private sectors, or with renunciation of social justice concerns, but with a range of progressive new social policies, including European ("Pakeha") - Maori biculturalism, 17 and equal employment opportunities for women, minorities, and the disabled. ${ }^{18}$

Some commentators suggest that the new rules of public management hold the potential to change not only administrative processes and procedures, but also the understanding of government itself. Combined with diminished public confidence in both electoral institutions and technocratic solutions, some observers envision an important cognitive shift within the bureaucracy to a new understanding of public management as "a process of state-citizen relations in which dialogue and deliberations between citizens and the agents of the state, especially public servants, constitute both a necessary and a sufficient response to the perennial questions of governance."19 For Aucoin, a management model with an awareness of its implications for governance generally would be based on three behavioral pillars:

First, greater attention must be given to the views of citizens in the design and delivery of public services. Second, sufficient authority must be devolved to those who are responsible for the operational aspects of public services, especially those on the front lines of service provision. Third, citizens must be well

Ibid. at 141-59. Biculturalism under the Labour administration was aimed at enhancing governmental responsiveness to Maori needs and cultural traditions, alleviating racial inequality, and addressing the Crown's obligations to the Maori people under the Treaty of Waitangi. The jurisdiction of the Waitangi Tribunal was broadened to allow for the investigation of Treaty claims back to 1840, Maori was made an official language, and Treaty principles were accorded statutory recognition in a number of important pieces of legislation. As well, an attempt was made to devolve the funding and control of many services provided by the Department of Maori Affairs to tribally based institutions. The National administration, which came to power in 1990, approached the situation from a more traditionally liberal philosophical perspective and modified the bicultural policy, while retaining the new public management model.

Ibid. at 246-57. See also K. Gover \& N. Baird, "Devolution and Maori Autonomy - Accidental Resonance? Liberal Democracy and Tribal Peoples: Group Rights in Aotearoa New Zealand" (New York University School of Law Symposium, 2 October 2000) [unpublished]. Kirsty Gover and Natalie Baird recently have suggested that the transformation of public administration and the evolution and articulation of Maori rights that took place over the same time period became symbiotically and complexly interrelated in practice. They argue that governmental policies of privatization and devolution, combined with effort toward coming to terms with Maori treaty claims, provided a space within which new Maori collectives and forms of autonomy emerged and proliferated. The more complex, fluid, and multidimensional notion of Maori identity that emerged necessarily changed the Crown/Maori relationship - and the government's institutions and strategies themselves. Gover and Baird suggest that, rather than attempting to restrict the debate between Maori groups on the proper loci of political representation, the Crown must accept that "the newly complex Crown/Maori interface has outgrown channelling devices, such as legislatively imposed tribal and pan-tribal structures." They argue in favour of a more passive Crown role that provides for an ongoing dialogue that can "further Maori aspirations for autonomy and well-being by permitting the sharing of information and strategies, allowing for inter-Maori discussion on relations between new and traditional groupings, and facilitating the collective Maori resolution of inter-group disputes." 
informed about the services to which they are entitled and the costs of these services; service targets and standards must be set for those providing them; and public managers and their organizations must be accountable for respecting citizen entitlements and meeting their targets and standards within the limits of the resources provided. ${ }^{20}$

The real challenge, however, is to integrate performance-based managerial models operating within a Westminster "impartial" public service with real-world politics and deeper social norms - in Aucoin's words, to address the question of whether "an effective accommodation can be reached in reforming both the partisan dynamics of responsible government and the non-partisan requirements of good government."21 Aucoin has noted that the idealized "post-bureaucratic paradigm," within which public sector actors manage their operations dispassionately and based entirely on objective outcome indicators, fails to take into account the realities of power, conflict, and competing interests in public administration - constraints that are the inevitable result of legitimate policy choices by elected representatives. ${ }^{22}$ For public decision making to be truly effective, therefore, management techniques such as best practices performance standards must be accompanied by clearly articulated fundamental policy objectives emanating from central policy-makers. ${ }^{23}$

Equally important, Aucoin argues that the ongoing challenge for the new public management style is to provide for the "missing link" of an accountability regime for public actors. Accountability to the democratic polity, through its elected representatives, can be improved through increased transparency in decision making, improved reporting and information sharing, and properly designed public performance audits. When coexisting with devolved decision making, accountability also requires a certain degree of political leadership from the centre, combined with structural safeguards to ensure that public servants are not forced to become politicized and that performance evaluations are premised on fact-based review rather than the vagaries of politics. ${ }^{24}$ Aucoin recommends establishing codes of ethics for public actors to manage the risk of devolving authority on such a widespread basis. He also argues that meaningful consultation with citizens, going beyond the mere expression of wants and demands, is crucial to designing and providing responsive and accountable public decision-making structures. Finally, citizens must have access to complaint and redress mechanisms to deal with administrative failures, through the courts if necessary. ${ }^{25}$

The New Public Management, ibid. at 10.

Ibid. at 256.

lbid. at 173-79.

Ibid. at 183-97.

Ibid. at 217-42. Importantly, the Westminster tradition of the impartial, permanent, and professional public service is more than attitudinal or symbolic. B. Ackerman, "The New Separation of Powers" (2000) 113 Harv. L. Rev. 633 at 696-707, has argued that American separation of powers doctrine leaves bureaucrats no stable base of political support, forcing them to behave in consciously political, short-term oriented ways. Parliamentarism, by contrast, gives bureaucrats strong incentives to behave with neutral competence and to take a long term perspective. See also B.G. Peters \& D.J. Savoie, "Reviewing the Reviewers: Program Review in the United States and Canada" in P. Aucoin \& D.J. Savoie, eds., Managing Strategic Change: Learning from Program Review (Ottawa: Canadian Centre for Management Development, 1998) 249 [hereinafter Learning from Program Review]. The New Public Management, ibid. at 217-40. 


\section{The New Public Management Model In Canada}

Canada was not as quick to adopt the new management style as were the other Westminster systems, perhaps due to a failure of political will under the Trudeau and Mulroney governments. ${ }^{26}$ Canada was also somewhat timid by comparison in terms of the scale of its reforms, preferring to engage in department-by-department analysis rather than a generalized review. ${ }^{27}$ Real change began in 1993 when then Prime Minister Kim Campbell announced a comprehensive overhaul of government and established a standing Regulatory Best Practices Committee within the federal Treasury Board. The new approach then guided the largest review of regulation ever undertaken at the federal level in Canada, under the government of Jean Chrétien, in 1993. Entitled "Program Review," it involved establishing best practices standards in government departments as diverse as Transport Canada, Health and Welfare Canada, and the Bureau of Competition Policy. Those standards were used to measure improvement, improve outcomes, and develop policy in several areas including delegating powers to the private sector, providing for stakeholder consultation, developing front-end assessment guidelines, consensus building, and evaluating alternative methods of securing compliance.$^{28}$ Government departments and external service providers were scrutinized on the basis of their ability to meet performance benchmarks set by other actors in terms of both outcome and process. Substantial institutional learning about managing strategic change and engaging the public service was acquired through the program review process. ${ }^{29}$

Since that time, new public management methods have become key tools for rationalizing public decision making and governmental structure. ${ }^{30}$ Alongside Program

Ibid. at 10-16, 141-51.

Ibid. at 10-19.

See Canada, Enlightened Practices in Regulatory Reforms, vols. 1, 2 (1992, 1993), online: <http://www.pco-bcp.gc.ca/default.asp?Language=e\&Page=Publications> (date accessed: $12 \mathrm{July}$ 2001). Recent Treasury Board publications concerning quality services, results-based management, accountability and review can be found online: <http://www.tbs-sct.gc.ca/pubpol_e.html> (date accessed: 25 August 2001).

See, for example, Learning from Program Review, supra note 24.

This is not to suggest that the story of the new public management in Canada has been entirely happy; far from it. Under both federal and provincial governments in the 1990s, the model was implemented in tandem with large-scale cost- and staff-cutting, which adversely affected the extent of improvement in public sector service provision and outcomes. While the model was cited as a justification, the cuts themselves were often deeper, broader, and seemingly more "checkerboard" in nature than careful application of a rationalizing model would have indicated. Moreover, the new public management had the historical misfortune of being championed by governments that lacked the credibility needed to get people "behind" such sweeping changes: many Ontarians have vivid memories of the dysfunction and outright rebellion that characterized Ontario's public service under Premier Bob Rae, for example. These stumbles are an important part of the story of the new public management in Canada, as elsewhere. Yet the experiments left their mark, and - apparently without exception - subsequent governments did not remove all traces of them and return to old organizational pathways. It appears that the experiments had long-term effects, in part, because even observers who worked toward recovering lost ground in public service provision realized that the bureaucratic disentrenchment and procedural opening up that came out of those years were not, in and of themselves, an unmitigated evil. Today one would be hard pressed to point to any government in Canada that has not been affected - either by internal design or the pressure of external example - by the new public management model and its correspondingly greater scope for collaborative 
Review and similar initiatives at virtually all levels of the traditional public sector and private sector-style management techniques in state-owned enterprises, new management models are operating in Canada in diverse public and semi-public forums including (to suggest only a few examples) the operation of housing co-operatives nationwide and the Municipality of Hamilton-Wentworth's VISION 2020 sustainable community initiative." At the provincial level, important experiments in community-based norm developmentand decision making have been taking place in health care policy in both British Columbia ${ }^{32}$

public/private decision making and its open-ended, pragmatically-oriented evaluative techniques. The prospect of returning to the old hierarchical structure becomes ever more remote as other social actors (including non-governmental organizations) discover and seize opportunities presented by the new structure and become accustomed to collaboration with, rather than dictates from, public servants. Descriptions of these and other initiatives are available through a "best practices clearing house" web site maintained by UNESCO's Management of Social Transformations Programme ("MOST"), online: MOST <http://www.unesco.org/most> (date accessed: 13 August 2001). The articles referred to above here are "Co-operative Housing in Canada: A Model for Empowered Communities," online: MOST <http://www.unesco.org/most/usa3.htm> (date acessed: 13 August 2001); and "Creating a Sustainable Community: Hamilton-Wentworth's VISION 2020," online: MOST <http://www.unesco. org/most/usa4.htm> (dated accessed: 13 August 2001). Details about the Hamilton-Wentworth's Regional Official Plan can be obtained online: <http:/www.vision2020.hamilton-went.on.ca>> (date accessed: 13 August 2001). Significantly, MOST is only one of several new Internet clearing houses directed at applying new management models to public service provision and the not-for-profit sector; another good web site is maintained by the Center for What Works, online: <http://www.whatworks. org> (date accessed: 13 August 2001).

The provincial government's health care policy reform, dubbed "New Directions," devolved decision making from the provincial Ministry of Health to community health councils ("CHC") and regional health boards ("RHB"). Originally the CHCs - some representing no more than a thousand constituents - were responsible for identifying local health priorities and setting policy to achieve these ends. The RHBs, of which there were 21 , were responsible for regional health planning and service coordination in order to retain some of the benefits of the economy of scale. (In 1996 the model was modified: there are now $34 \mathrm{CHCs}, 11 \mathrm{RHBs}$, and 7 community health services societies ("CHSS"). The CHSSs have assumed the CHCs' responsibilities for community health services, and the CHCs now deal only with acute and long term care. The general philosophy of the New Directions initiative remains unchanged.) By statutory design, health care priorities and provision mechanisms at all levels are subject to regular re-evaluation. The Ministry of Health provides support, rather than direction, to the communities and regions; sets broad guidelines respecting core health services; and facilitates communication between the local units. Although the local decision-making bodies are defined by geography, the New Directions scheme also mandates broad community participation on CHCs, CHSSs, and RHBs. In particular, communities are required to ensure that historically marginalized groups and those with special health care needs (e.g., women, the elderly, the disabled, and ethnic or cultural minority groups) are represented adequately. All community boards must have at least one Aboriginal representative. Involvement by other community players, including poverty advocates, school boards, and health care workers and providers is strongly encouraged. I have discussed these initiatives in "Democracy, Health, and Place: A Review of the New Directions Policy Initiative in British Columbia" (1996) [unpublished] [hereinafter "Democracy, Health, and Place"]. See also British Columbia Ministry of Health and Ministry Responsible for Seniors: New Directions for a Healthy British Columbia (Policy Document, February 1993); and British Columbia Ministry of Health and Ministry Responsible for Seniors, Processes, Benchmarks and Responsibilities for Developing Community Health Councils and Regional Health Boards (Policy Document, May 1994). The model has been successful and continues to operate in British Columbia with some modifications arising out of its implementation (Letter from P. Chuly to C. Ford (7 March 2000)). The Ministry's Homepage <http:/www.gov.bc.ca/healthservices/> provides resources to health care practitioners, citizens, and communities in the province. Its 1999-2002 Strategic Directions Report may be found online: Ministry of Health Services <http:/www.hlth.gov.bc.ca/cpa/ 
and Ontario ${ }^{33}$ since 1993.

Many of these projects are promising demonstrations of how productive connections between public, social, and private spheres are possible through centralized coordination of communication; local establishment of rolling best practices standards and benchmarking; transparent procedure; and broad-based stakeholder participation. As significant new forms of governance, however, each is incomplete. Particularly in those projects that take community-based decision making seriously - such as Ontario's Healthy Communities Project - what is often missing, as Aucoin has suggested, ${ }^{34}$ is accountability: both of the centre to the local units and of the local units generally. That is, although community groups are encouraged to engage in benchmarking and rolling best-practice rule making, nothing in the administrative or regulatory architecture of the programs critically evaluates their success in using these methods. They are not challenged to "bootstrap" their effectiveness upward by comparison with other groups. Local coalitions concerned about health care are not answerable to citizens, the central office,

publications/strategic/pdf> (date accessed: 13 August 2001).

The Ontario Healthy Communities Coalition ("OHCC") is based on the World Health Organization's "Healthy Cities" Project, and unlike the B.C. model, it is adjunctive rather than central to provincial health care provision. Its goal is to "build healthier communities" (defined broadly) through a process characterized by wide community participation, broad intersectoral involvement in decision making, local government commitment, and interaction with "healthy public policy" at the provincial level. The OHCC seeks to foster sustainable links between government and health-related projects that originate independently at the community level. With the assistance of an OHCC regional resource person, the local initiative is provided with capacity-building resources and guided through strategic planning, dispute resolution, and coalition-building. The OHCC emphasizes the participatory, processoriented, pragmatic and local nature of the model and the importance of using pre-existing provincial associations as networks for reaching into the communities' civil society and for providing support in the form of resources and in-kind services. Once formed, the community coalition is coached through a series of steps including interacting with local govemment; identifying key players; developing an intersectoral approach and a "working structure" to coordinate the process; and developing a plan of action. At each step coalition members are expected to evaluate their work and plan for the next step in order to develop benchmarks and establish rolling best practice standards. If information (obtained through networking) leads a coalition's members to believe that a project should be implemented in partnership with another local coalition, that process is facilitated through the OHCC. Similarly, community coalitions are encouraged to examine other communities' experiences to determine whether and how their methods could be improved. Coalitions are encouraged to seek external funding for their programs and to design them to be self-supporting where possible. The OHCC Board of Directors is not a funding or authoritative body; it establishes only broad project guidelines to be implemented by community organizations. The OHCC also maintains a central office - a clearing house designed to support local coalitions and initiatives, identify resource people at the community level, and develop networks to train, problem solve, and exchange information among communities. It publishes a regular newsletter and recognizes local coalitions' success stories, both on paper and the Internet. It also maintains print, electronic and video resource libraries on process, evaluation and indicator tools, and organizing skills for the communities' use, as well as a national and international Peer Resource List and Network. Community initiatives pursued through the OHCC to date include the development of alternative transportation networks, child nutrition programs, job creation programs, tourist promotion initiatives, improved health care access programs, and programs for community policing and reducing violence in schools. Cooperative ventures between adjacent groups have also led to new committee structures in some areas. The OHCC web site is online: OHCC <http://www.opc.on.ca/ohcc> (date accessed: 13 August 2001). 
or the board of directors (though they are answerable to private funders) for failure to meet benchmarks, or even for failure to set them in the first place. In short, they are not subject to the kind of performance and process standards that the Canadian government sets for service providers and its own departments during Program Review. Without such structures in place, the community groups are not equipped to establish firm standards or actually to implement policy. Correspondingly, while the clearing house engages in networking, it does not institutionalize learning and push the reflective process to its full potential, which would entail having the communities critically review their own outcomes and actually participate in generating larger norms. Moreover, because the groups need not answer to the centre for the inclusiveness, contestability, or transparency of their processes, ${ }^{35}$ the local experiments risk being captured by small groups of citizens. ${ }^{36}$ Thus, while such initiatives are important first steps in recognizing the value and effectiveness of broadly participatory, community-based decision-making processes, one must expect the programs' individual community success stories to remain discrete, disjointed, and somewhat accidental. Without reciprocal accountability and institutionalized learning, they do not translate into an effective and deeply legitimate large-scale model for public administration or governance.

\section{A NEW THEORY OF GOVERNANCE}

Paradoxically, perhaps, the Westminster systems were able to become international leaders in public management reform for two primary reasons related to the high degree of concentrated authority that characterized them. ${ }^{37}$ To begin with, as a structural matter

See J. Cohen \& C. Sabel, "Directly Deliberative Polyarchy" (1997) 3 Eur. L.J. 313 at 327-30. [hereinafter "Polyarchy"]. The requirement that reasons be given is a central component of legitimate participatory decision-making practices, particularly in pluralist contexts. Giving reasons provides a clear "paper trail" to assist courts and others in evaluating the decision-makers' proposal, and it keeps the process transparent. Giving reasons is also an important way to demonstrate respect for the other stakeholders in the deliberations. It forces people to be more other-regarding and (in the inevitable case of disagreement) makes it easier for those who do not get their way to understand and accept their loss. Subjecting decisions to "peer review" also gives parties an incentive to ground their arguments on shared beliefs where possible and exerts a centripetal and focusing effect on the deliberations. See also S. Sturm, "A Normative Theory of Public Law Remedies" (1991) 79 Geo. L.J. 1357. She argues that faimess, participation, and reasoned and principled conduct are basic principles of legal legitimacy.

This may be a problem in the British Columbia Health Care scheme where CHC, CHSS, and RHB board members serve for fixed terms. Moreover, they are appointed by the Ministry of Health rather than elected by the community. Somewhat controversially, the Ministry tries to use the appointment process to prevent "special interest" board capture and ensure adequate representation. It has periodically overridden local communities' appointment recommendations in favour of an outside appointment. See "Democracy, Health and Place," supra note 32.

In Europe, by contrast, it was the strength of the national governments and the weakness of the central regulatory institutions that made devolution and industry-driven reforms the only obvious and politically viable solution. In a fascinating convergence, it turns out that similar developments have been occurring in the European Union, though catalyzed by entirely different forces. Theoretical developments are also proceeding along very analogous lines. The "New Approach" to harmonization was launched through a Council Resolution in 1985 ("Council Resolution on a new approach to technical harmonization and standards, OJ 1985 C 136/1.") The complete storyline, running through the judgment of the European Court of Justice in Cassis de Dijon, the White Paper, and the multiple transformations that took place in 1992 following Maastricht, is found in C. Joerges et al., "European 
the executive branches of these Commonwealth governments are granted a high degree of discretion (as compared to the American system of divided government) to change the machinery of government without seeking legislative change. Second, as compared to other parliamentary systems in which coalition governments are more the norm, each of these systems was run by strong parliamentary majority governments at the time of the model's implementation. This gave those governments the luxury of avoiding partisan disagreement and compromise. ${ }^{38}$

A transformation in public management policy has not taken place in the United States with anything like the degree of coordination or comprehensiveness that existed in New Zealand, or even in Canada. ${ }^{39}$ In the practice of government-regulated economic and social activity, however, private sector organizational theory has carried over into a range of organized decision-making processes similar in philosophy and operation to the new public management model. ${ }^{40}$ More important for present purposes, the most explicitly articulated and comprehensively imagined theoretical model for a new style of governance deriving from that practice has come from the United States. While building on the same identifiable trends in administrative and regulatory practice, the model of "democratic

Product Safety, Internal Market Policy and the New Approach to Technical Harmonisation and Standards" EUI Working Papers LAW 91/10-14 (European University Institute, Department of Law, Florence), online:European University Institute <http://www.iue. it/LAW/WP-Texts/Joerges $91 />$ (date accessed: 13 August 2001). Other accounts include K.A. Armstrong \& S.J. Bulmer, The Governance of the Single Market (Manchester: Manchester University Press, 1998) and E. Vos, Institutional Frameworks of Community Health and Safety Regulation. Committees, Agencies and Private Bodies (Portland: Hart Publishing, 1999). The European regulatory initiatives developed out of the desire to harmonize national technical directives in the interest of market integration. Because there was no political choice in the face of established national regulatory schemes, the Union limited itself to developing broad guidelines, leaving the drafting to national governments and the standard-setting to the regulated industries themselves on the basis of their own best practices. Only recently has the debate arrived at considering the larger social, democratic, and rights implications of such steps, including the need to ensure that consumer and environmental interests are also consulted. Yet the so-called "democratic deficit" in EU institutions and policy implementation is only one of the the ongoing and vastly different issues to be resolved. The European scholarship on new forms of governance is exceptionally sophisticated and deserves a comparative treatment in much greater depth than is possible here; it is the project of their age. Some of the most interesting recent treatments include C. Joerges, H. Schepel \& E. Vos, "The Law's Problems with the Involvement of NonGovemmental Actors in Europe's Legislative Processes: the Case of Standardisation Under the 'New Approach"' EUI Working Paper LAW 99/9 (European University Institute, Department of Law, Florence), online: European University Institute <http://www.iue.it/LAW/WP-Texts/Jeorges99/>; B. Kohler-Koch \& R. Eising, eds., The Transformation of Governance in the European Union (New York: Routledge, 1999); J. Peterson \& E. Bomberg, Decision-Making in the European Union (New York: St. Martin's Press, 1999); and A. Héritier, "The accommodation of diversity in European policy-making and its outcomes: regulatory policy as a patchwork" (1996) 2 J. Eur. Pub. Pol. 149. The New Public Management, supra note 10 at 5.

39 Ibid. at 19. A brief comparative review of early 1990s regulatory reform under the Chretien government and the Clinton administration (including an important cautionary point on the vast differences between the parliamentary and presidential systems and the limits of comparative analysis of macrolevel policy development) is offered by Peters \& Savoie in Learning from Program Review, supra note 24.

40 "DE," supra note 8. The authors discuss initiatives in family support services at 324-27; community policing at 327-32; nuclear power plant safety at 371-73; historical antecedents in forestry at 364-71; military procurement at 332-36; and public health at 416-17. 
experimentalism" developed by Michael Dorf and Charles Sabel goes further than mere reform to existing public management structures, no matter how normatively significant that reform may be.

Obviously, theories on governance originating in the United States, Canada, and the European Union are as complexly different from each other as the societies and circumstances that give rise to them. I am unapologetic about throwing them particularly the Canadian and American streams - together into an unstable cocktail for the sake of furthering what seems to be a very important discussion. I nod periodically to some profound differences in theory, but (to use another metaphor) this article is not an attempt to untangle the various threads that go into a national political philosophy; it is more an attempt to weave some faintly exotic threads into the fabric in the interest of enriching it. Canada has something to gain in considering possible extrapolations from public management traditions that are already established in its practice. Particularly when discussing the constitutional issues facing Quebec, it makes sense to speak of democratic experimentalism rather than of the new public management because democratic experimentalism takes existing management theory to logical but much more far-reaching conclusions in the service of larger social goals. Thus it seeks to address Aucoin's concerns about linking accountability with good government, discusses democracy in explicit terms, and entrenches constitutional safeguards for a nation's fundamental rights and values.

\section{a. Origins and Attributes of Democratic Experimentalism}

Democratic experimentalism is a challenging theoretical model for the practice of constitutionalism. It proposes a framework for a novel way of making public decisions, characterized by a directly democratic process of ongoing, open-ended elaboration and revision of both means and ends. ${ }^{41}$ It draws insights from a wide variety of sources, including organizational and management theory, philosophical pragmatism, radical democratic and civic-republican political theory, and a tradition of practical public interest lawyering.

Like the new public management model, the immediate roots of democratic experimentalism are in organizational and management theory. Because new public management models were not implemented comprehensively in the United States, Dorf and Sabel construct their analysis directly from a study of structural process changes that

Dorf and Sabel's article, ibid., is a theoretical articulation, in the constitutional context, of a model that Sabel has also applied to a number of other specific contexts. See also C. Sabel, D. O'Rourke \& A. Fung, "Stepping Up Labor Standards," with A. Fung \& D. O'Rourke, (February/March 2001) 26 The Boston Review 4; J. Liebman \& C. Sabel, "The Emerging Model of Public School Governance and Legal Reform: Beyond Redistribution and Privatization" (Montreal Conference of Collective Rights, Identity and Public Education, June 2000), online: through Sabel's web page at <http://www.law.columbia.edu/sabel/papers.htm> (date accessed: 25 August 2001); and C. Sabel, A. Fung, \& B. Karkkainen, After Backyard Environmentalism: Toward a Performance-Based Regime of Environmental Regulation (Boston: Beacon Press, 2000) [hereinafter Backyard Environmentalism]. For this article, an important companion piece has been Polyarchy, supra note 35, which considers aspects of social deliberations between groups within a pluralistic society. 
have taken place in the private sector over the last few decades. They argue that changing market forces and the influence of so-called "new management theory" catalyzed a series of radical shifts in management style and organization in private industry in North America. Specifically, many corporations have shifted away from familiar hierarchical, rigid decision-making structures in favour of more pragmatic, team-based organizing principles that rely on continuous information exchange and collaboration among key players to identify, consider, and realize the corporation's objectives. ${ }^{42}$ Dorf and Sabel then go on to argue that these organizing principles of the "new management" are not confined to the private sector, and that in several fields of government-regulated economic and social activity, the organizational principles employed by government regulators have also changed to reflect the changing organizational structure of the sectors they regulate. ${ }^{43}$

Strikingly, although each "national" perspective developed somewhat independently of the others, there are unmistakable convergences between the developments that Dorf and Sabel describe in the United States and the new public management in Westminster (as well as market integration-driven policies in the European Union). The outstanding characteristic of the new regulatory model that Dorf and Sabel observe is the decentralization of decision-making power, coordinated loosely through a centralized regulatory agency. These innovative regulatory agencies do not seek definitive answers to empirical and policy questions. Rather, they set temporary standards of industry conduct, which are based upon the best practices to emerge from industry actors in communication with one another. For example, rather than specifying a particular means of carrying out an industry task, regulators attempt to define the ends to be achieved by reference to existing industry standards of best practice. Those ends are subject to an ongoing process of re-evaluation and modification as required, a process known as "rolling best-practice rule making." $\$ 4$ The process is characterized throughout by continuous, nonhierarchical and effective communication directed at the common goal of appropriate industry regulation, largely as defined by the parties themselves. Thus in the new regulatory model, industry stakeholders participate directly in the formulation of policy through the development and constant retooling of rolling best practices standards; regulators participate in the activities they regulate through ongoing, two-way communication with their constituents and coordination between different industry players; transparent procedures marked by ongoing dialogue, accountability, and constant review limit the parties' opportunities to capture the process and to engage in self-interested conduct.

Dorf and Sabel argue that administrative agencies are particularly well-suited to this kind of flexible decision-making structure due to their proximity to the industries they regulate, their expertise in setting standards and coordinating participation and deliberation across groups, and their demonstrated ability (at least in some industries) to benchmark the standards they themselves provide by reference to the rolling best practice standards

"DE," ibid. at 292-314.

Ibid. at 324-36, 364-73, 416-17.

Ibid. at 350-54. 
of their constituents. ${ }^{45}$ The new structure, in turn, increases the agencies' claim to democratic legitimacy. ${ }^{46}$ However, the assumption behind democratic experimentalism as a more general model - and the point at which it leaves New Public Management behind - is that these new-style organizing principles can be applied to the institutions of democratic governance generally. Dorf and Sabel argue that as society has become more complex and interdependent, the centralized, hierarchical, and inflexible government structures that have characterized the American administrative system since the era of the New Deal - including not only old-style administrative rule making but, strikingly, current practices of judicial review and representative majority rule government - have become increasingly ill-suited to responding to rapidly evolving social needs and goals. ${ }^{47}$ The most ambitious observation of democratic experimentalism is that the "fundamental and widely diffused changes in the organization of cooperation" in certain regulated forums provide the basis for "a renewed understanding of the concepts of freedom and equality of citizens that form the common heritage of modern constitutional democracies." ${ }^{48}$

The democratic experimentalism model is philosophically located within the pragmatic philosophical tradition, which for Dorf and Sabel assumes

[an] account of thought and action as problem solving in a world, familiar to our time, that is bereft of first principles and beset by unintended consequences, ambiguity, and difference. Thus, a central theme $\ldots$ is the reciprocal determination of means and ends: ... the objectives presumed in the guiding understandings of theories, strategies, or ideals of justice are transformed in the light of the experience of their pursuit, and these transformations in tum redefine what counts as a means to a guiding end. Pragmatism thus takes the pervasiveness of unintended consequences, understood most generally as the impossibility of defining first principles that survive the effort to realize them, as a constitutive feature of thought and action, and not as an unfortunate incident of modern political life.49

DE seeks to give form to this pragmatic experiment through a "Madisonian project" of direct deliberation, resting on a "bedrock of respect ... for diverse, changing understandings of the world, and the contentious varieties of individual and group life they inform, as antecedent to and protected by the Constitution." on this point, anyway, with the civic republican school of thought and with the critical legal studies school that preceded it, Dorf and Sabel describe constitutional development as an ongoing, argumentative process through which a society continually defines and redefines itself along with its priorities and aspirations. The democratic experimentalism model reflects an understanding of democracy that goes beyond the "thin" liberal sense of the term to require active participation from the polity. For modern republicans like

4 Ibid. at 438-44. A primary impetus for the model is a perceived crisis in modem American constitutionalism. In the context of the separation of powers and federalism doctrines set out by the framers of the American Constitution, the legitimacy of the modern, undemocratic, post-New Deal administrative state is questionable (ibid. at 270-72). See also Ackerman, supra note 24. "DE," ibid. at 270-78, 283-85, 306-307.

Ibid. at 290.

Ibid. at 284-85.

Ibid. at 289. 
Dorf and Sabel, ${ }^{51}$ properly functioning democratic deliberation is an ongoing, argumentative process properly characterizednot only by a respect for individual rights, but also by a strong sense of political participation and active citizenship. Democratic experimentalism imagines a collaborative method of social problem solving that can only occur through an ongoing, open-minded and respectful dialogue between social stakeholders, primarily at the level of direct democracy.

Along with pragmatism and civic republicanism, democratic experimentalism can also be located within recent streams of critical/deconstructionist thinking on democracy. In particular, democratic experimentalism shows the influence of Roberto Mangabeira Unger's important (if controversial) work on "radical democracy" as a neo-Jeffersonian theory of society based on a flexible, plastic structure that encourages and assumes constant revision by human agents. Unger points out the relevance of underlying institutional structures, what he calls "formative contexts," 52 in shaping and limiting peoples' imaginative assumptions about the range of options available to them. $\mathrm{He}$ criticizes existing social democratic norms for insulating their fundamental institutions from deep criticism and revision, for overemphasizing technocratic solutions to political problems, and for miring the delivery of social services in a bureaucratic, procedural ethic that disempowers and disengages citizens. ${ }^{33}$ Unger advocates creating structures that are capable of deinsulating aggregated power (both in privileged populations and areas of governance) from democratic control. He asserts that a comprehensive understanding of citizens' legal rights should include "destabilization rights," which would allow citizens to challenge existing hierarchies of power and privilege and empower them to prevent factions from gaining a long-term hold upon the levers of social power. ${ }^{54}$

At the societal level, Unger argues that "false necessities," such as entrenched social roles, groups, and hierarchies (including public markers of identity such as cultural affiliation, as well as the very distinction between public, social, and private spheres of action) also inhibit human freedom, creativity, and participation. Moreover, these inhibitors are closely related to the structures embedded in a society; in fact, Unger asserts that "group alliances and antagonists are always just the reverse side of a set of

See also B. Barber, Strong Democracy: Participatory Politics for a New Age (Berkeley: University of California Press, 1984); J. Cohen, On Democracy: Toward a Transformation of American Society (Markham, Ont: Penguin Books, 1983); F. Michelman, "Symposium: The Republican Civic Tradition: Law's Republic" (1988) 97 Yale L.J. 1493. For Canadian readers: civic republicanism should not be confused with the American Republican political party or its platform or with the republican system of government that can be distinguished from constitutional monarchies like Canada's. The term refers to the seminal political debate - still a crucial one in American political theory - between James Madison's view of democracy as a highly participatory civic model based on informed debate among group and individual interests within the polity, and Thomas Jefferson's more individualist "libertarian" model (which ultimately triumphed among the framers of the American Constitution).

R.M. Unger, Politics: Social Theory: Its Situation and Its Task (Cambridge: Cambridge University Press, 1987) at 130-31. Democracy (Cambridge: Cambridge University Press, 1987) at 585-86. [hereinafter False Necessity]. 
institutional arrangements and a sequence of institutional reforms."ss Unger, like democratic experimentalism, asserts that people become more fully empowered by breaking down such stable social groups and revising the associated institutions and "imaginative contexts" that society, itself, creates. Real, legitimate democracy must incorporate deep and direct popular participation in governance, meaningful control over processes and institutions, and broad-based investment in democratic decision making. It requires new forms of human association and far-reaching institutional change. ${ }^{56}$ Ultimately, democratic experimentalism represents such a radical democratic shift in decision-making processes and institutions.

One of the main differences between Unger's theories and civic republicanism is that republicanism is prepared to locate deliberation anywhere and generally assumes that it takes place in the formal "public sphere" - separate and distinct from practical action in the "social sphere" of the community and civil society. ${ }^{57}$ Unger, and by extension democratic experimentalism, rejects the distinction between the private, social, and public spheres as a self-imposed constraint on human creativity, and he advocates a public decision-making model that seamlessly integrates these interconnected and equally important facets of individual and group life. However, democratic experimentalism also diverges materially from both civic republicanism and Unger's elegant theoretical model in one important respect: democratic experimentalism sees deliberation as only possible and effective when it occurs together with practical action. In this context, the introduction of, for example, the best practices standard for participation enables democratic experimentalism to avoid the attack on its relevance faced by the more theoretical models. ${ }^{58}$ Democratic experimentalism is very much informed by a tradition of progressive social lawyering, which emphasizes pragmatic results and values the influence that law can have on specific public interest issues. ${ }^{59}$ Dorf and Sabel recognize that, in its current incarnation, democratic experimentalism has yet to provide an entirely satisfactory response to, for example, entrenched inequality in society. They do not see the problem as a fatal flaw in the model, however, but as an ongoing social issue. Because it is well suited to direct, democratic and participatory decision making in the complex

R.M. Unger, Democracy Realized: The Progressive Alternative (New York: Verso, 1998) at 13. See R.M. Unger, The Critical Legal Studies Movement (Cambridge: Harvard University Press, 1986) and the three volumes of R.M. Unger, Politics: $A$ Work in Constructive Social Theory (Cambridge: Cambridge University Press, 1987). See also Jonathan Turley's review of Unger's program: J. Turley, "Introduction: The Hitchhiker's Guide to CLS, Unger, and Deep Thought" (1987) 81 Nw. U.L. Rev. 593.

H. Arendt, On Revolution (New York: Viking Press, 1977).

Ungerian radical democracy, in particular, is criticized for failing to take seriously the rights of minorities and the problem of inequality in real-world societies. Scholars like Drucilla Comell, Cass Sunstein, and Cornel West assert that Unger's vision of the supreme, "transcending self" fails to account for different conceptions of human identity that emerge from feminist and communitarian jurisprudence, among others. In addition, they argue generally that Unger's program is acontextual and exists purely in the realm of the "imagined life," to the detriment of its relevance to the important social and political issues that confront ordinary people and communities: D. Cornell, "Beyond Tragedy and Complacency"; C.R. Sunstein, "Routine and Revolution"; C. West, "Between Dewey and Gramsci: Unger's Emancipatory Experimentalism" (1987) 81 Nw. U.L. Rev. at 693, 869 and 941 , respectively.

See, for example, R. Cover, "The Supreme Court, 1982 Term — Nomos and Narrative" (1983) 97 Harv. L. Rev. 4 at 9. 
and volatile context of modern society, they argue that such problems are at a minimum no less capable of amelioration through democratic experimentalism than through other existing methods of democratic representation..$^{60}$

\section{b. Democratic Experimentalism and Constitutional Discourse}

Democratic experimentalism is at its most innovative and most challenging in attempting to employ the community-based decision-making tools described above to the problem of constitutional rights discourse. Employing democratic experimentalism beyond the administrative context and into the constitutional one requires that three fundamental elements of current constitutional arrangements be re-evaluated: federalism and the division of powers, rights discourse, and the role of the courts.

The impact of democratic experimentalism on federalism can be addressed briefly here given the differences between Canadian and American federalism in terms of their allocation of responsibilities between federal and subnational (state or provincial) units. ${ }^{61}$ For now, the essential point is that under democratic experimentalism, the central government actor is relegated to a less pivotal position in public problem solving than it holds under traditional models. For example, although the federal government (in the United States, Congress) would initiate and perhaps finance an experimental social program, the local or municipal government (or a community group, or some other subnational decision-making structure) would actually do the experimenting based on its determination of the priorities and essential community norms that emerge from its own experimental process. The national state catalyzes and coordinates local activity and sets general guidelines with respect to objectives. It then leaves the precise end products to the local bodies' imagination, so long as their experimental methods conform to rolling best practice standards of participation and decision making. In order to be effective decisionmakers, however, those subnational institutions must be substantially more flexible than many existing governmental structures, and they must be organized along the pragmatic, problem-solving lines of the new organizational style. In Dorf and Sabel's words,

these subnational jurisdictions do not have natural boundaries to their power. ... For it is only by continually adjusting these boundaries that the jurisdictions can, in fact, be effective problem solvers. ... [Federalism's] central theme, from the vantage point of democratic experimentalism, would no longer be the (impossible) search for immovable boundary stones marking the limits of federal and state power, but

"DE," supra note 8 at 408-10. See also Susan Sturm's work on deliberative decision making in public remedies, supra note 35, and in workplace discrimination: S. Sturm, "Race, Gender and the Law in the Twenty-First Century Workplace: Some Preliminary Observations" (1998) I U. Pa. J. Lab. \& Emp. L. 639 at 687-88.

Martha Field, an American scholar, provides a helpful comparative overview of Canadian federalism in "The Differing Federalisms of Canada and the United States" (1992) 55 L. \& Contemp. Probs. 107. The moral foundations of Canadian federalism, in contradistinction to the American ones, also have been the subject of some recent attention: see S.V. Laselva, The Moral Foundations of Canadian Federalism: Paradoxes, Achievements, and Tragedies of Nationhood (Montreal: McGillQueen's University Press, 1996). The definitive text on the structure and operation of Canadian constitutionalism is P.W. Hogg, Constitutional Law of Canada 4th ed. (Toronto: Carswell, 1997) [hereinafter "Hogg"]; federalism is discussed at Chapter 5. 
rather the definition of general standards for determining the just and effective division of sovereignty with regard to particular public problems. ${ }^{62}$

As a result, decision making becomes a decentralized, pragmatic, and flexible process coordinated loosely through an overarching facilitating body, and it is based on notions of community-based norm development and direct deliberation. Centralized monitoring for compliance with goals and best practices is maintained at the national level, which uses local developments as benchmarks to measure and evaluate local practice.

More directly relevant to present purposes, Dorf and Sabel go on to argue that it is not logically possible to limit the implications of democratic experimentalism to the structural/procedural aspects of public law, such as federalism or administrative decision making. Taken to its logical extension, democratic experimentalism must also become a means for translating the community's most deeply held beliefs and values (about liberty, democracy, rights and equality) into practice. In turn, actually practicing those beliefs at the community level, when accompanied by the kind of conscious and structured evaluative process they have in mind, will necessarily affect the community's understanding of the beliefs themselves. Crucially, in the context of the rights discourse that inevitably accompanies public problem solving deliberations, the democratic experimentalist process requires that the community's norms themselves be open to critical discussion at some level.

Dorf and Sabel readily acknowledge that democratic experimentalism is at its most controversial in asserting that fundamental values can safely be subjected to this sort of open-ended deliberative process. ${ }^{63}$ Like civic republicanism and philosophical pragmatism, the model introduces a radical element of democratic indeterminacy - of experimentalism - into a nation's constitutional bedrock. That element seems particularly worrisome in the context of a rights discourse that implicates the protection of minority interests or the equality of historically disregarded or disadvantaged sectors of society. Unlike civic republicanism or philosophical pragmatism, however, democratic experimentalism responds by defining and insisting on a conscious, self-reflexive decisionmaking structure, based on rolling best practices rule making, to house that conversation about rights.

The authors make the point that new elaborations on fundamental constitutional principles should properly arise from the experimentalist process. To begin with, they argue that their model of rights reflects a more honest view of what everyone actually means by the word rights in postmodern, post-structuralist thought. Citing a wide range of contemporary thinkers, the authors argue that there exists a degree of "awkward consensus" in contemporary rights talk. ${ }^{64}$ This consensus recognizes that individual rights

"DE," supra note 8 at 420 . Dorf and Sabel discuss American federalism in a more nuanced fashion

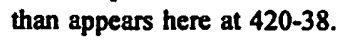

63 Ibid. at 404.

of Ibid. at 446-52. Among others, they mention Dworkin, Rawls, Ackerman, Benhabib, Gilligan, Walzer, Sandel, Rorty, and Raz. They could probably have included some of the Critical Race Theorists as well: see, for example, R. Delgado, "The Ethereal Scholar: Does Critical Legal Studies Have What Minorities Want?"; M. Matsuda, "Looking to the Bottom: Critical Legal Studies and 
(both as concepts and in their contemporary forms) are historically contingent constructions that cannot be seen without reference to the particular communities within which they are located; but as motivating ideals, rights continue to retain their persuasive force. They assert that

there is agreement that commitments to rights to freedom and equality are part of our identity as members of democratic societies. Apparently, our rights do not lose their majestic and independent authority when we come to acknowledge that in some sense we chose them. Because our rights are part of who we are, they shape, explicitly or not, all the manifold projects by which we determine the future of our polities. Indeed, ... given the centrality of rights to our political identity, we cannot imagine a future for our polities at all without contemplating how we shall affirm or modify our rights. ${ }^{\text {os }}$

The authors observe that political rights and personhood are mutually defining. Citing Joseph Raz," they point out that a sort of "feedback loop" exists between the individual's definition of herself and her society's definition of the possibilities and capacities available to her. In the context of rights, the identities and capacities of both the individual and the group (or groups) are jointly negotiated and determined. ${ }^{67}$ Thus the mutual recognition of rights is crucial to individual identity, and it serves as an approximate political and practical expression of our individual humanity. Rights and identity are mutually dependent.

This historically contextualized and shifting view of rights is consistent with the pragmatist nature of democratic experimentalism. In fact, Dorf and Sabel argue that socalled "experimentalist rights" are the only rights that we as citizens have or have ever had. $^{68}$ Democratic experimentalism acknowledges that rights are not based on first principles; that inevitably they are socially constructed and historically contingent; and that they are closely connected with both individual and group identity. ${ }^{69}$ Allowing a community to describe and define rights on its own terms grants explicit recognition to an interplay between rights and identity that is taking place anyway. Moreover, as a function of this honesty and of its flexible principles, democratic experimentalism holds out the potential of discovering "new and reconcilable understandings of rights"70 through the active and direct discussion it engenders. The authors assert that

Reparations"; and P. Williams, "Alchemical Notes: Reconstructing Ideals from Deconstructed Rights," in (1987) 22 Harv. C.R.-C.L. L. Rev. 301, 323, and 401, respectively. "DE," ibid. at 448.

J. Raz, "Right-Based Moralities" in J. Waldron, ed., Theories of Rights (New York: Oxford University Press, 1984) 182.

"DE," supra note 8 at 448-49.

Ibid. at 452. Here, of course, the general spirit of the article parts ways with some of the other thinkers the authors cite. See, in particular, Ronald Dworkin's criticism of philosophical pragmatism in R. Dworkin, Law's Empire (Cambridge: Harvard University Press, 1996) c. 4.

"DE," ibid. at 470-73. In doing so, the authors suggest that paradoxes inherent in constitutional amendment and deliberation in the United States, which are related to the originalist-revisionist debate about constitutional meaning that has attracted so much attention in American scholarship, may begin to dissolve through the process of direct constitutional deliberation.

Ibid, at 451. 
[e]xperimentalism does not name an alternative to the identification of Platonic rights. It names an organized, considered alternative to a haphazard mixture of metaphysical nonsense and ungrounded speculation about empirical matters."

Further, Dorf and Sabel argue that, thus organized, an open-ended and pragmatic deliberative process is an especially effective mechanism for talking about constitutional rights and values, both in terms of the results it can hope to achieve and in terms of its legitimacy. They assert that democratic experimentalism is a "relentless and deliberate application" of the liberal faith in the ability of freedom and cooperation to improve the human condition:

Decentralized experimentalism can be an instrument for increasing participation, or, put the other way, reducing exclusion, and [for] connect[ing] ... to the large hopes of what is sometimes called Enlightenment or liberal thought. ... [D]emocratic experimentalism by its very nature enlarges the range of alternatives under consideration [by] drawing the participants beyond the circle of their habits and routines by exposing them to unfamiliar projects and prospects. ${ }^{n}$

Clearly, these ambitions are well beyond anything contemplated in the regulatory and community-based spheres, though they are not beyond the ambitions of some European thinkers. ${ }^{73}$

Because the most basic rights are at stake in constitutional deliberation, Dorf and Sabel ascribe a pivotal role to the courts. In imagining an actual mechanism for the intersecting constitutional rights protection with these new forms of democratic governance, democratic experimentalism goes crucially beyond anything happening in either European or Westminster theory. Under democratic experimentalism, courts protect fundamental legal norms in two primary ways. First, they are responsible for setting out, at a high level of abstraction, the framework of essential rights and values within which the democratic experiment is to proceed. For example, a court could require that political actors observe the fundamental principles of equal protection (as, perhaps, judicial review based on the 14th Amendment does in the United States). In articulating the principles upon which the discussion must be based, the court ensures that the fundamental characteristics of that liberal democratic society are upheld. However, the court would not go a step further and set out concrete plans (for example, affirmative action programs, school voucher programs, or electoral district reform) that translate those values into practice. Each community is free to develop means to give effect to the broader value, tailored to its own needs and priorities. Thus courts are not forced to pretend that they can imagine all the possible real-life consequences of recognizing a particular right or make sweeping decisions about which precise mechanism is the most effective mechanism for protecting that right. ${ }^{74}$

Ibid. at 457.

Ibid. at 405-407.

Supra note 37.

"DE," supra note 8 at $388-97$. 
Second, and equally importantly, courts are the essential instrument for ensuring that local political decision-makers observe participatory and transparent procedures in their deliberations, thereby avoiding self-dealing and enforcing accountability. The whole trajectory of decision making does not have to be retraced in the process; rather, the court checks for compliance with procedural "best practices." It looks critically at the information used by the decision-maker, including its own changing responses to challenges and proposed alternatives. The court considers the decision-maker's participatory methods, its capacity for evaluating its own results, and its capacity for adapting to new information. In the constitutional context, then, the court would have to be satisfied that the decision-making body had ensured adequate participation for stakeholders, including minorities and historically disadvantaged groups. Embedded in the idea of adequate participation are elements of what might be termed "procedural due process," including provision of a respectful hearing, due notice, and access to information. $^{75}$

In scrutinizing the decision-maker's reasoning, courts would have to satisfy themselves that the decision-making process had taken into account obligatory considerations (such as the affirmative text of a constitution) and had ignored impermissible arguments. The decision-maker would also have to demonstrate the institutional ability to reflect critically on the results of its own and other experiments and other standards of "best practices." Having the decision-maker provide reasons for its decisions is important to each of these evaluations. In short, the decision-maker would be required to demonstrate that it had respected the spirit of legitimate, equal, and dynamic deliberation. ${ }^{76}$ Courts would only defer to the decision-makers' experimentalist decisions (for example, to guarantee equal protection in a novel manner) once they had been satisfied with the steps the decisionmakers took and the constituencies that participated in developing their plan. ${ }^{77}$

Dorf and Sabel point out that courts are particularly suited to evaluating decisionmaking processes in a relatively dispassionate way, while leaving the nice balancing of competing social interests (an area in which their legitimacy is subject to greater attack) to the realm of politics. Moreover, the court is not required to speculate ex post facto about justifiable bases for implementing the proposed program; the onus is on the

It is beyond the scope of democratic experimentalism (and, in fact, incompatible with its argument) to lay down a blueprint of exactly how courts could ensure meaningful participation; mechanisms would evolve through studied experimentation. But it should be pointed out that we know an increasing amount about what "meaningful participation" practically entails, and people are talking about it. See, for example, Susan Sturm's work, supra note 35. One of the points of this article is that, by their nature, the substantial constitutional principles set out in the Quebec Secession Reference also illuminate what "procedural due process" in public decision making actually means. See Part III.B.2, below, for more on this topic. "DE," supra note 8 at $388-400$.

$n \quad$ For an opposing view, see M. Tushnet, Taking the Constitution Away from the Courts (Princeton, NJ: Princeton Univerity Press, 1999). Tushnet argues for a system of populist constitutional law within the framework of existing representative democratic institutions. Like democratic experimentalism, Tushnet's approach emerges out of the pragmatic and civic-republican political traditions. Unlike Dorf and Sabel, however, Tushnet favours representative democracy over direct democracy. In addition, he objects to the non-democratic quality of the judiciary and argues for eliminating constitutional judicial review in its entirety. 
decision-maker to provide reasons for advocating the policy it does, based on its own participatory best practices and benchmarks from other local bodies.

Dorf and Sabel assert that courts can already be seen using this kind of analysis in judicial review. Citing cases like Miranda v. Arizona ${ }^{78}$ and the work of David Strauss, ${ }^{79}$ the authors assert that American courts already adopt so-called "prophylactic rules" where they identify conditions that threaten constitutional values, without necessarily being able to identify a clear violation or to predict the precise causal chain by which that threat will come to pass. In those circumstances, courts establish minimum, general preventive standards (such as the "Miranda rights" of suspects in the United States to discourage coerced confessions following arrest) ${ }^{80}$ and they then encourage other actors with more specific knowledge of the circumstances to clarify or improve upon the means by which that rights-protective goal can be met. For Dorf and Sabel, such judicial attempts to give effect to deeply established but vague constitutional norms, while leaving the means of protection open to political experimentation, represents a central role for the courts under DE. ${ }^{81}$

With these elements of the democratic experimentalist approach in hand, I now turn to the next building block in this argument: the constitutional situation in Quebec on the question of secession following the Supreme Court of Canada's Secession Reference of August 1998. It would be surprising to discover that the Court was explicitly aware of the emerging scholarship on new forms of governance (although it may well have been influenced more subtly by the changing face of public management generally in Canada). Nevertheless, in important respects, the Supreme Court's decision could be framed as an example of democratic experimentalist judging in action: the Court has articulated a framework of fundamental constitutional principles within which the question of Quebec's secession is to be determined. In its emphasis on a legitimate and respectful process of public discourse, it has also required local political decision-makers to demonstrate that

384 U.S. 436 (1966).

D.A. Strauss, "The Ubiquity of Prophylactic Rules" (1988) 55 U. Chi. L. Rev. 190.

Since the advent of the Canadian Charter of Rights and Freedoms, Part I of the Constitution Act, 1982, being Schedule B to the Canada Act 1982 (U.K.), 1982, c. 11 [hereinafter the Charter] in 1982 , s. 10 of which addresses rights on arrest or detention, these rights have been accorded constitutional protection in Canada and there has been no need for courts to develop analogous prophylactic rules. For non-Canadian readers: the Constitution of Canada is composed of two primary documents: the Constitution Act, 1867 (formerly the British North America Act, 1867) and the Constitution Act, 1982. The Charter is part of the second document.

"DE," supra note 8 at 452-57. C.R. Sunstein, One Case at a Time: Judicial Minimism on the Supreme Court (Cambridge, Mass.: Harvard University Press, 1999) develops a fairly compatible argument within a different terminological framework. Through a discussion of the United States Supreme Court's recent decisions in the areas of affirmative action, discrimination on the basis of sex and sexual orientation, the right to die, and issues of free speech, Sunstein argues for a particular "democracy-promoting" brand of judicial minimism characterized by commitment to a core of constitutional values and the exercise of restraint in attempting to tum those core values into ambitious statements or clear, final rules. (In Chapter 4, he attempts to lay down the "core" commitments with, likely, greater specificity than did the Supreme Court of Canada: see text accompanying note 54.) Sunstein asserts that properly exercised, this sort of judicial restraint promotes democracy by leaving issues open for democratic deliberation and by promoting reasongiving and accountability in the political process. 
they have observed participatory "best practices" in developing a mandate on secession. However, the actual working out of the issue is thrown back to the public sphere for resolution. Yet, the Secession Reference is more than a convenient ruling on which to hang a democratic constitutional experiment in Quebec. The principles it sets out are of the very kind that the experiment itself would desperately need: no attempt at directly deliberative decision making in a pluralistic society like Canada's could afford to do without built-in safeguards for constitutional rights and minority protection in particular. In effect, the Secession Reference is a stunningly appropriate touchstone for managing the difficult balance between constitutional rights and democracy itself, and in this respect it makes a significant contribution to the theory of democratic experimentalism.

\section{B. Proposing an Experiment}

\section{QUEBEC AND THE SECESSION REFERENCE}

Democratic experimentalism is a comprehensively imagined model supported by concrete examples of its application in isolated administrative contexts. ${ }^{82}$ Similarly, the literature on network governance in the European Union is supported by seemingly unmistakable trends from the regulatory sphere. ${ }^{83}$ Yet, perhaps unsurprisingly, nowhere have these theories been put into actual practice in their most ambitious forms, as mechanisms for articulating and developing community-based fundamental constitutional norms. Translating a model like democratic experimentalism to the larger democratic context is a much riskier proposition than is applying it to the local decision-making process. The potential social cost of the change could not be taken lightly so long as existing models of constitutionalism, democracy, rights discourse, and judicial review continued to function relatively well. ${ }^{84}$

A chronic crisis exists in Quebec. The last twenty years have seen two referendums in that province on the question of secession from Canada (in 1980 and 1995). ${ }^{85}$ In addition, the years since the first referendum have been characterized by an increasing

The New Public Management, supra note 10 at 19.

Supra note 37.

In fact, the history of new public management and regulatory reform in the United States would seem to suggest that some kind of crisis is necessary to catalyze even more modest changes in regulatory and administrative structures. As noted above, the crisis in the Westminster systems derived from a profound loss of credibility and straitened economic circumstances. The crisis in Europe derived from the utter failure of other means for market integration. Similar crises were the impetus for regulatory changes in environmental law in the United States: Backyard Environmentalism, supra note 41.

More accurately, the first referendum was on a question of "sovereignty-association" under which the Quebec government sought a mandate to negotiate with Canada for an arrangement wherein Quebec would "acquire the exclusive power to make its laws, administer its taxes and establish relations abroad ... and at the same time, to maintain with Canada an economic association including a common currency." The Quebec voters rejected that referendum question by a majority of 59.5 percent to 40.5 percent. The same two decades have also seen two failed attempts on the part of the Canadian government to amend the nation's Constitution Act, 1982, being Schedule B to the Canada Act 1982 (U.K.), 1982, c. 11 to persuade Quebec to become a signatory to it. The so-called Meech Lake Accord failed to be ratified on June 23, 1990; the Charlottetown Accord failed by referendum on October 26, 1992. See Hogg, supra note 61 at \$5.7. A brief history of Canada's constitutional difficulties is available on uni.ca, supra note 5 . 
sense of nationalism and cultural distinctiveness on the part of francophone Quebecers. Quebec is, of course, a unique francophone-majority culture surrounded by a dominant North American anglophone-majority culture. The francophone majority (though not monolithic) in many cases traces its roots to the settling of New France prior to 1763, and it has a strong sense of a common French heritage and a bond to the province's physical territory. The imperative toward la survivance of French Canadian culture and language has given rise to a series of controversial language laws in Quebec and to an independence movement commanding broad-based public support, including support from the young and intellectual elites. At the same time, the social, economic, and political fabric of Quebec is deeply entwined with that of the rest of Canada. Moreover, the face of Quebec is increasingly multicultural, multilingual, and globally oriented. Alongside the population that bears francophone family names, Quebec (and especially its largest city, Montreal) is home to long-standing ethnic and anglophone communities and to a large and growing immigrant population (the "allophones") whose first language is neither French nor English. Northern Quebec in particular is home to a number of increasingly politically active Aboriginal (or "First Nations") communities. Multiculturalism is a reality throughout the province, as it is in the rest of Canada, and Quebec's philosophical and political thought continues to be shaped by the persistent diversity of its society.

In this context, on October 30,1995, the separatist government of Premier Jacques Parizeau held a referendum in Quebec on the following question:

Do you agree that Quebec should become sovereign, after having made a formal offer to Canada for a new economic and political partnership, within the scope of the Bill respecting the future of Quebec and the agreement signed on June $12,1995 ?^{26}$

An incredible $94.5 \%$ of the eligible population turned out to vote. And $49.4 \%$ of the popular vote answered "yes" to the referendum question. The referendum precipitated a political crisis in Canada outside of Quebec, as well as in Quebec's anglophone and allophone communities. Canada began to wrestle seriously with the unanswered question

The "Bill" referred to, and popularly known, as Bill 1 was actually a draft bill tabled by Parizeau in Quebec's National Assembly on December 6, 1994, entitled, An Act respecting the sovereignty of Québec. The "Bill" was endorsed on June 12, 1995, in a Tri-Partite Agreement by the then-leaders of the Parti Québécois, Bloc Québécois, and Action Démocratique, Messrs. Parizeau, Lucien Bouchard and Mario Dumont respectively. It says, among other things, that if the referendum returns a majority affirmative vote, Quebec is committed to propose a treaty of economic and political partnership to Canada. The treaty would cover many issues, including the free-flow of money, goods, and people between the two areas; citizenship; and Quebec's possible use of the Canadian dollar as a monetary unit. The Bill states that one year after negotiations are supposed to begin, it will be open to Quebec's government to proclaim the national sovereignty of Quebec, irrespective of whether the negotiations with the rest of Canada have been successful. The Internet is a good source of background information on Quebec sovereignty, Canadian constitutionalism, and the referendum. A fairly well-connected (though aging) English web site is Quebec Referendum on the Web - 1995 Archival Information, online: Intemet Sources for Journalists and Broadcasters $<$ http://www.synapse.net/ radio/refer.htm> (date accessed: 13 August 2001). Uni.ca, supra note 5, is also useful. An exceptional French-language chronology of Quebec history is "Chronologie de l'histoire du Québec" online: <http://www.citeweb.net/hist/ien/can-que.html> (date accessed: 13 August 2001). 
of what an affirmative vote would have meant for the country. After substantial political wrangling, the Canadian federal government brought a constitutional reference ${ }^{87}$ to the Supreme Court of Canada on, inter alia, the following question: "Under the Constitution of Canada, can the National Assembly, legislature or government of Quebec effect the secession of Quebec from Canada unilaterally?"88 The Supreme Court handed down its ruling on August $20,1998 .^{89}$ Nothing done since by either federal ${ }^{90}$ or provincial ${ }^{91}$

Section 53 of the Supreme Court Act, R.S.C. 1985, S-26 gives the Supreme Court of Canada the ability - and the obligation - to render advisory opinions on questions referred to it by the executive branch of the federal government. The section states that "the Govemor in Council [i.e., the Parliamentary Cabinet] may refer to the Court for hearing and consideration important questions of law or fact" and further, on the making of such a reference, "it is the duty of the Court to hear and consider it and to answer each question so referred." The Court addressed the constitutional validity of the provision in the Secession Reference, supra note 6 at paras. 6-15, commenting on the strict "case or controversy" and federal separation of powers restrictions in the United States and the European model of abstract constitutional review. The Court upheld the constitutionality of the reference provision. It noted that there was nothing inherent in the nature of the Court that would prevent it from exercising such a role and observed that the Canadian Constitution does not insist on a strict separation of powers. The Court went on to find that the questions submitted to it were within the purview of s. 53, that it had jurisdiction over the subject matter, and that the questions were justiciable (Secession Reference, ibid. at paras. 16-31).

Secession Reference, ibid. at para. 2. Cabinet also asked the Court to determine whether international law gave Quebec the right to secede from Canada unilaterally (as a function of a possible right to self-determination or otherwise); and, in the event of a conflict between the answers provided under domestic and international law, Cabinet asked the Court to determine which of the two takes precedence in Canada. The Court denied that Quebec possessed a right to secession under the principle of self-determination of people at international law, as that principle only applied where "a people" was governed as part of a colonial empire; where "a people" was subject to alien subjugation, domination or exploitation; and possibly where "a people" was denied any meaningful exercise of its right to self-determination within the state of which it formed a part. The Court found that none of these conditions applied in Quebec on the facts and, therefore, declined to decide whether the Quebec government constituted "a people." Because it found no conflict between domestic and international law, the Court did not have to decide which of the two would take precedence in Canada (ibid. at paras. 109-47).

The govermment of Quebec refused to take part, stating that the issues at stake were political and for the people of Quebec alone to decide. An amicus curiae was appointed to put forward a position for Quebec. Shortly after the Secession Reference was initiated but before it was heard by the Court, the Canadian Bar Association commissioned two academic articles "as contributions to the questions raised." See H. W. MacLauchlan, "Accounting for Democracy and the Rule of Law in the Quebec Secession Reference" (1997) 76 Can. Bar Rev. 155, which provides a concise review of the history of the Secession Reference, the position of the parties, and the justiciability of the secession question. With the benefit of hindsight, the article by R. Howse \& A. Malkin, "Canadians are a Sovereign People: How the Supreme Court Should Approach the Reference on Quebec Secession" (1997) Can. Bar Rev. 186, makes fascinating reading with respect to the normative bases on which the Court could address the problem before it.

Bill C-20 became An Act to give effect to the requirement for clarity as set out in the opinion of the Supreme Court of Canada in the Quebec Secession Reference, 2d Sess., 36th Parl., 2000 (assented to 29 June 2000, S.C. 2000, c.26). This ordinary statute commonly known as the Clarity Act provides that, should a provincial government officially release a referendum question that it intends to submit to its voters relating to proposed secession from Canada, the Canadian House of Commons shall consider the question and set out its determination as to whether that question is "clear." In doing so, the House of Commons shall consider "whether the question would result in a clear expression of the will of the population of a province on whether the province should cease to be part of Canada and become an independent state." This clear expression explicitly cannot result from two kinds of referendum question: one that would only seek a mandate to negotiate with the rest of Canada 
elected representatives has served to settle the debate about Quebec's future with the rest of Canada. ${ }^{92}$

After deciding that neither jurisdictional limitations nor the allegedly non-justiciable nature of the issues barred it from accepting the reference, ${ }^{93}$ the Court addressed the relevant historical bases, written and unwritten, of Canada's constitutional architecture. It formulated its ruling on the question of secession by reference to what it found to be four

without soliciting a direct expression on secession itself; or one that "envisages other possibilities in addition to the secession of the province from Canada, such as economic or political arrangements with Canada, that obscure a direct expression of the will of the population of that province on whether the province should cease to be part of Canada." The Clarity Act states that the government of Canada shall not enter into negotiations on secession if it determines that the referendum question is not clear (s. 1). In addition, following any such referendum, the government of Canada shall not enter into negotiations on secession unless it determines that there has been "a clear expression of the will of a clear majority of that province in favour of secession." Criteria for defining the "clear majority" include the size of the majority in favour of secession, the percentage of eligible voters who took part in the referendum, and anything else that the House of Commons considers relevant (s. 2). The statute also insists a province's secession from Canada would require an amendment to the Canadian Constitution; and that no minister of the Crown shall propose such an amendment "unless the Government of Canada has addressed, in its negotiations, the terms of secession that are relevant in the circumstances, including the division of assets and liabilities, any changes to the borders of the province, the rights, interests and territorial claims of the Aboriginal peoples of Canada, and the protection of minority rights" (s. 3).

Quebec's response to the Clarity Act was Bill 99, which became An Act respecting the exercise of the fundamental rights and prerogatives of the Québec people and the Québec State, 1st Sess., 36th Leg. Quebec, 2000 (assented to December 13, 2000), S.C. 2000, c. 46. The Quebec Act's Preamble describes the Clarity Act as a federal legislative initiative "that challenge[s] the legitimacy, integrity and valid operation of [Quebec's] national democratic institutions." It states that "the Québec people is the holder of rights that are universally recognized under the principle of equal rights and selfdetermination of peoples," and that "the Quebec people alone, acting through its own political institutions, has the right to decide the nature, scope and mode of exercise of its right to selfdetermination." It describes a winning vote on a referendum to be "fifty percent of the votes cast plus one" (Chapter I). Among other noteworthy provisions, the statute goes on to affirm Quebec's sovereignty over the whole of its territory (in Chapters II and III) and states that "no other parliament or government may reduce the powers, authority, sovereignty or legitimacy of the National Assembly" (Chapter IV). On May 5, 2001, a small anglophone political party in Quebec, the Equality Party, brought an action in Quebec Superior Court seeking to have portions of the Act declared unconstitutional; the petitioners' motion is available online: <http://www.vigile.net/01-5/ henderson.html> (date accessed: 25 August 2001). See also G. Wanamaker, "Quebec hauled into court" CNEWS Politics (17 May 2001), online: <http:/www.canoe.ca/CNEWSPolitics0105/17_ wanamaker-can.html> (date accessed: 25 August 2001).

It is, moreover, a fundamental assumption of this article that separatist sentiment in Quebec is a longstanding historical phenomenon, not the product of an individual politician or party. Lucien Bouchard, until recently the separatist Premier of Quebec and head of the Parti Québecois, resigned on January 11, 2001, citing the independence movement's lack of success. F. Tomesco, "Quebec's Bouchard Quits, Citing Separatism's Failings" Bloomberg (11 January 2001), online: Bloomberg <http://quote.bloomberg.com/newsarchive/wnarchive.cgi> (date accessed: 14 August 2001). While this move robbed the Parti of one of its most charismatic personalities, I argue that Quebec's internal division and its frustration with Canadian federalism has not evaporated with his departure. The province's new premier, Bernard Landry, recently expressed his "profound wish" to hold another election on the question of sovereignty before 2005. See R. Séguin, "Landry sees new vote on sovereignty by 2005" Globe and Mail (20 August 2001) Al. 
fundamental organizing principles that informed and sustained the Canadian constitution: federalism, democracy, constitutionalism and the rule of law, and respect for minorities. ${ }^{94}$ The Court stated that no single principle could be defined in isolation from the others; nor did any one principle trump or exclude the operation of any other. ${ }^{95}$

With respect to "federalism," the Court found that the adoption of a federal form of government was an essential act of nation building for Canada, without which the agreement of the various (now provincial) actors could not have been obtained. Federalism is "the political mechanism by which diversity could be reconciled with unity," "a political and legal response to underlying social and political realities," and a crucial recognition of "the diversity of the component parts of Confederation, and the autonomy of provincial governments to develop their societies within their respective spheres of jurisdiction." ${ }^{166}$ The federal system allows citizens to express themselves in a variety of forums, at both regional and national levels. ${ }^{97}$

The Court stated that democracy, in the sense of the "supremacy of the sovereign will of a people," is a fundamental value in Canadian constitutional law and political culture that implies more than mere majority rule. ${ }^{98}$ It stated:

Democracy is not simply concerned with the process of government. On the contrary ... democracy is fundamentally connected to substantive goals, most importantly, the promotion of self-government. Democracy accommodates cultural and group identities.... Put another way, a sovereign people exercise its right to self-govemment through the democratic process. In considering the scope and purpose of the Charter, the Court in $R$. v. Oakes ... articulated some of the values inherent in the notion of democracy:

"The Court must be guided by the values and principles essential to a free and democratic society which I believe to embody, to name but a few, respect for the inherent dignity of the human person, commitment to social justice and equality, accommodation of a wide variety of beliefs, respect for cultural and group identity, and faith in social and political institutions which enhance the participation of individuals and groups in society."99

What follows is a review of the principles of the Secession Reference tailored to my particular argument. The Secession Reference has, of course, attracted a great deal of outstanding analysis already. See, for example D. Schneiderman, The Quebec Decision: Perspectives On The Supreme Court Ruling On Secession (Toronto: J. Lorimer, 1999); P. Monahan, "The Public Policy Role of the Supreme Court of Canada in the Secession Reference" (1999) 11 N.J.C.L. 65; S. LaSelva, "Divided Houses: Secession and Constitutional Faith in Canada and the United States" (1999) 23 Vermont L. Rev. 771; J-F. Geaudreault-DesBiens, "The Quebec Secession Reference and the Judicial Arbitration of Conflicting Narratives About Law, Democracy and Identity" (1999) 23 Vermont L. Rev. 793; and (1998) 10:1 Const. L. Fonum, which is an issue devoted to the Quebec Secession Reference. Secession Reference, supra note 6 at para. 49.

Sections 91 and 92 of the Constitution Act, 1867, (U.K.), 30 \& 31 Vict., c. 3, reprinted in R.S.C. 1985, App. II, No. 5, sets out the division of powers between the federal and provincial governments respectively.

Secession Reference, supra note 6 at paras. 35-47, 55-60.

Ibid. at para. 61.

Ibid. at para. 64 [footnotes omitted]. Interestingly, the Court is broadening significantly the plain meaning of the term "democracy" by reference to $R$. v. Oakes, [1986] I S.C.R. 103. The Oakes case was, in fact, a relatively early post-patriation constitutional case that set down the above description of the "free and democratic society" (which presumably implies more than the simple "democratic 
With respect to the third principle, "constitutionalism and the rule of law," the Court drew on a series of its significant constitutional references taken over the last twenty years to conclude that the rule of law is a "highly textured" concept. Most basically, it implies that there is one law for all; that an actual order of positive laws that preserves and embodies the more general principle of normative order must be created and maintained; and that the relationship between the state and the individual must be regulated by law. ${ }^{100}$ The rule of law provides the framework within which the people's sovereign will is to be ascertainedand implemented. In turn, that legal system derives its legitimacy from its accountability to the democratic will. ${ }^{101}$ Augmenting the rule of law, the principle of constitutionalism provides that all government action must be in accordance with the Constitution, which is the "supreme law of Canada" and the source of legitimate government authority in the federation. In addition to providing for the division of political power in the federalist system, the Constitution is entrenched beyond the reach of simple majority rule in order to ensure that fundamental human rights and freedoms are respected and that vulnerable minority groups are protected. ${ }^{102}$

The Court was least expansive on the meaning of the fourth (and already vague) animating principle of Canadian constitutionalism, "respect for minorities." It observed that in practice, the protection of minorities has often been the product of historical political compromises, with the result that provisions for minorities in Canada have been oriented toward according religious, educational, and linguistic rights to cultural and linguistic minorities in particular. In addition, the three other constitutional principles have also "inform[ed and sometimes presumably limited] the scope and operation of the specific provisions that protect the rights of minorities." Nevertheless, the Court asserted that the broader principle of respect for minorities is the product of a tradition "at least as old as Canada itself," and it is an independent organizing principle of the constitutional order. The Court linked respect for minorities with the principle of constitutionalism and the rule of law only by reference to three incarnations of the principle: the explicit individual rights provisions set out in the Charter; the historical statutory provisions respecting minority rights in the areas of language, religion, and education; and the

society") in a particular factual matrix: the Court was construing the meaning of section 1 of the Charter, which states: "The Canadian Charter of Rights and Freedoms guarantees the rights and freedoms set out in it subject only to such reasonable limits prescribed by law as can be demonstrably justified in a free and democratic society." Whether the Court would have described the free and democratic society in the same terms were it construing a rights-enabling clause, rather than a rightsrestricting one, is not clear. In R. v. Keegstra, [1990] 3 S.C.R. 697 Dickson C.J. commented that the notion of the "free and democratic society" is the commonality that "links the guarantee of rights and freedoms to their limitation."

100 Secession Reference, ibid. at paras. 70-71.

101 Ibid. at paras. 66-67.

102 Ibid. at paras. 72-74. Louis Henkin sets out a set of "essential characteristics of constitutionalism" in rather broader terms. Along with the protection of individual human rights, Henkin's formulation, paraphrased, also subsumes: the rule of law (including judicial constitutional review); a higher standard for constitutional amendments than the simple majority; the existence of an independent judiciary; the separation of powers; limited government; popular sovereignty and accountable democratic government; and civilian control of the police and the military. L. Henkin, "Elements of Constitutionalism" Occasional Paper Series, Center for the Study of Human Rights, Columbia University (1992). 
protection of the rights of Aboriginal peoples, which "whether looked at in their own right or as part of the larger concern with minorities, reflects an important underlying constitutional value."103

The subtle ways in which the Court interconnects the other animating principles helps to explain what is meant by "respect for minorities." Setting out the connections requires quoting from the judgment at some length. To begin with, democracy is related to the federalism principle in that federalism allows the sovereign will of the people to be expressed concurrently in different collectivities. The federal structure also facilitates democratic participation by distributing power to the government most suited to dealing with a given social objective. ${ }^{104}$ Those different collectivities, however, also play a role in protecting minority rights:

The principle of federalism facilitates the pursuit of collective goals by cultural and linguistic minorities which form the majority within a particular province. This is the case in Quebec, where the majority of the population is French-speaking, and which possesses a distinct culture. This is not merely the result of chance. The social and demographic reality of Quebec explains the existence of the province of Quebec as a political unit and indeed, was one of the essential reasons for establishing a federal structure for the Canadian union in 1867 .... The federal structure adopted at Confederation enabled French-speaking Canadians to form a numerical majority in the province of Quebec, and so exercise the considerable provincial powers conferred by the Constitution Act, 1867 in such a way as to promote their language and culture. It also made provision for certain guaranteed representation within the federal Parliament itself. $^{105}$

The principle of respect for minorities also reconciles the theoretical tension between constitutionalism and democracy. The Constitution, including the Canadian Charter of Rights and Freedoms, is entrenched beyond the reach of simple majority rule precisely because respect for minorities is essential to, rather than in conflict with, the "richer" principle of democracy that informs the Canadian system: ${ }^{106}$

[A] constitution may provide an added safeguard for fundamental human rights and individual freedoms which might otherwise be susceptible to government interference. Although democratic government is generally solicitous of those rights, there are occasions when the majority will be tempted to ignore fundamental rights in order to accomplish collective goals more easily or effectively. Constitutional entrenchment ensures that those rights will be given due regard and protection. Second, a constitution may seek to ensure that vulnerable minority groups are endowed with the institutions and rights necessary to maintain and promote their identities against the assimilative pressures of the majority. ${ }^{107}$

Finally, each of the organizing principles is held together through a "rich" practice of democracy, characterized by full and effective participation of all groups in society; an

Secession Reference, ibid. at paras. 79-82. Beyond its articulation of the above historical rights and the rights of Aboriginal peoples, the Court does not attempt to set out how a "minority" is to be identified. See Part III.B.2, below, for more on this topic.

los Ibid. at para. 59 [emphasis added]. 
assortment of forums in which groups as well as individuals can pursue their interests; and a government structure that is accountable to the expression of the sovereign will as so defined. The goal of the democratic process is not simply to determine the will of the majority or to enforce consensus. The Court described democracy, rather, as an ongoing process of respectful and pragmatic public deliberation, negotiation, argument, and collaboration through which society continues to define and examine itself and its goals:

[A] functioning democracy requires a continuous process of discussion. The Constitution mandates government by democratic legislatures, and an executive accountable to them, 'resting ultimately on public opinion reached by discussion and the interplay of ideas'.... At both the federal and provincial level, by its very nature, the need to build majorities necessitates compromise, negotiation, and deliberation. No one has a monopoly on truth, and our system is predicated on the faith that in the marketplace of ideas, the best solutions to public problems will rise to the top. Inevitably, there will be dissenting voices. A democratic system of government is committed to considering those dissenting voices, and seeking to acknowledge and address those voices in the laws by which all in the community must live. ${ }^{108}$

In the final analysis, the Court applied the four constitutional principles to the secession context and held that there, too, an obligation to negotiate existed. It concluded that any effort on the part of Quebec to secede from Canada must derive its legitimacy from the clear expression of a democratic will to so do. Therefore, a "clear majority" vote by the people of Quebec on a "clear referendum question" in favour of secession would be necessary. Such a vote would require the other provinces and the federal government to enter into negotiations with Quebec. ${ }^{109}$ Those obligations would be reciprocal, such that neither Quebec nor the rest of Canada could dictate terms to the other. Further, the democratic principle expressed in the secession vote, while accorded due respect, would have to be tempered by due consideration for the other constitutional values. ${ }^{110}$ Significantly, the Court described "a 'clear' majority as a qualitative evaluation"" and pointed out that

[t] he other provinces and the federal government would have no basis to deny the right of the government of Quebec to pursue secession, should a clear majority of the people of Quebec choose that goal, so long as in doing so, Quebec respects the rights of others. ... Negotiations would need to address the interests of the other provinces, the federal government, Quebec and indeed the rights of all Canadians both within and outside Quebec, and specifically the rights of minorities.

Ibid. at para. 68 [footnote omitted].

Ibid. at paras. 87-88.

Ibid. at paras. 85-88. See also generally paras. 89-105.

Ibid. at para. 87 [emphasis added]. It must be pointed out that the Court sets out the need for a qualitative majority only once in the judgment. It does not define the term apart from saying that "the referendum result, if it is to be taken as an expression of the democratic will, must be free of ambiguity both in terms of the question asked and in terms of the support it achieves." Nevertheless, I have made the concept of a clear qualitative majority - as opposed to a quantitative majority, no matter how large - central to my argument because it seems to capture, in a word, a sense of the broad range of considerations that the Court insists must be evident in a legitimate, broad-based, and inclusive constitutional democratic process. In particular, the Court's discussion of the democratic principle in the Secession Reference (ibid. at paras. 63-69) informs my understanding of the term "qualitative." 
The negotiation process would require the reconciliation of various rights and obligations by negotiation between two legitimate majorities, namely, the majority of the population of Quebec, and that of Canada as a whole. A political majority at either level that does not act in accordance with the underlying constitutional principles we have mentioned puts at risk the legitimacy of its exercise of its rights. ${ }^{12}$

The Court warned that such negotiations would be exceedingly difficult, that no one could predict the course of them, that there could be no guarantee of success in the negotiations, and that even in the event of a clear majority vote in Quebec on a clear question, there was no absolute legal entitlement to secession. The Court also referred, obliquely, to the possibility that the provincial boundaries of Quebec could be challenged in the secession context. ${ }^{113}$ Ultimately, however, the Court acknowledged the political nature of the process. It stated that in defining the precise nature of the obligation to negotiate, it was confronted with "the difficult inter-relationship between substantive obligations flowing from the Constitution and questions of judicial competence and restraint in supervising or enforcing those obligations." 114 It left the precise articulation of those constitutional obligations to the negotiating parties themselves, should the need ever arise.

\section{DEMOCRATIC EXPERIMENTALIST JUDGING}

A strong case can be made that the Supreme Court of Canada's ruling on the Secession Reference illustrates the principles of democratic experimentalist judging in action. This is not to suggest that the Court literally or consciously saw itself as a player in a new kind of governance, though it may have been familiar with the broad themes of new public management models. Nevertheless, the Court's judgment can be cast into the courts' role of protecting fundamental legal norms, as Dorf and Sabel have envisioned it. Specifically, the Supreme Court has articulated, in general terms, those essential substantive rights and values that delimit the boundaries within which the democraticnegotiation should proceed: federalism, democracy, constitutionalism and the rule of law, and respect for minorities. The Court does not, however, attempt to prescribe a precise mechanism by which those organizing principles should be made manifest, much less what they require in the context of a Canada-Quebecnegotiation on secession. Nor does the Court attempt to prescribe the conclusive "proof" the Quebec government would require to demonstrate that it was reflecting the will of a "qualitative clear majority" of its people, should it demand negotiations with Canada. For example, the Court deliberately refuses to set out what percentage of the popular vote would satisfy its threshold legitimacy requirement. It also leaves open what degree of demonstrated respect for rights, the rule of law, and minorities are required or how those prerequisites will be established. In addition, it openly acknowledges that it is in no position to imagine the possible consequences of a clear

Ibid. at paras. 151-52. As noted above, the Secession Reference obviously deals with the negotiation procedure between Canada and Quebec; however, my focus continues to be on developing a framework for constitutional deliberation within Quebec, using the principles set out in the Secession Reference as guidelines.

Ibid. at para. 96. The possibility that Quebec itself could be divided in the event of a "yes" vote is an exceptionally charged political issue in Canada. This so-called "Plan B" was raised publicly by Prime Minister Jean Chrétien shortly after the 1995 referendum, to the great alarm of both federalists and sovereigntists in Quebec (as well as many people in the rest of Canada). lbid. at para. 89. See also generally paras. 85-105. 
affirmative vote in favour of secession - beyond the requirement for a negotiation with Canada - or to predict the course of those negotiations.

Second, in describing the Constitution's animating principles as it has, the Court has moved a substantial distance toward developing a framework for the actual process of the secessionist deliberations. The principles the Court sets out - and the principles of democracy, respect for minorities, and the clear qualitative majority in particular - are the standard by which Quebec's deliberative process will be judged. In effect, the Court is saying that it is prepared to defer to the elected representatives of Quebec (and to require the Canadian government to negotiate with those representatives) to the extent that they can demonstrate that a responsible, democratic, and broadly participatory process within Quebec has given them a secessionist mandate. Quebec must show that its mandate is accountable to the popular will and that it was achieved within the bounds of "obligatory considerations," such as the rule of law and the text of the Canadian Constitution (including those individual rights fundamental to the smooth operation of the democratic machinery, such as freedom of speech and association). It must demonstrate adherence to an ongoing negotiative process and to substantive outcomes emanating from that process that ensure adequate participation and protection for social and political stakeholders, including minorities and other historically disadvantaged groups such as women. Quebec must develop its democratic mandate through a process of "compromise, negotiation, and deliberation" that, by definition, acknowledges that there is no "monopoly on truth."115 Thus deliberation and participation must be "rolling," in democratic experimentalism language, in that the process requires the Quebec government to respond to challenges and actively consider other models and proposed alternatives that emerge from the public discussion.

Third, as is appropriate in serious constitutional discourse, the Court has allocated political and judicial roles in a way that balances democratic pressures with the protective mechanisms that constitutional rights require in any pluralistic and unequal society. The Court's emphasis on a highly participatory and open-ended deliberative method recommends it to a situation in which fundamental questions going to Quebec's very identity are at stake. The method also seems better-suited to the difficult task of reaching an accommodation between the many different constituencies in Quebec society than does a one-time yes/no vote or an attempt to impose an artificial consensus. The judgment recognizes that democratic process is the essential source of constitutional legitimacy. However, in constructing the Secession Reference as it has, the Court has reserved to the judiciary the equally crucial function of constitutional judicial review, to ensure that the majority will respects the principles of Canadian constitutionalism and does not do violence to the rights of minorities. In setting the goal of the process at the level of the "clearqualitative majority" the Court is mandating a democratic process that demonstrably protects local cultures and autonomy, reconciles unity with diversity, and provides for minorities' self-determination while safeguarding democracy. ${ }^{116}$

In order for the Secession Reference judgment to have "bite" in the real world, courts, governments, and society must have some meaningful way of evaluating whether 
Quebec's deliberative process is actually meeting the standards established. This is, of course, one of the motivating sentiments behind the Canadian federal government's Clarity Act. ${ }^{117}$ My argument here is that new public management theory and democratic experimentalism provide more appropriate tools - rolling best practices rule making, benchmarking, systematized learning - for evaluating that process. In the Secession Reference, the Supreme Court of Canada has described the rights-protective and processprotective role that courts must play to transform new public management structures into something like a democratic constitutional experiment. ${ }^{118}$ With these counterpoised democratic and constitutionalist foundations in place, a procedural structure to support a respectful and accountable social argument becomes an imaginative possibility.

The ultimate question about democratic experimentalism, however, comes down to whether one believes that it can actually coexist with the kind of balancing that all pluralist and unequal societies must carry out in the interest of constitutional rights and social fairness. This is hardly a problem that is unique to Canada: the disjuncture between constitutional values and democratic ones is an old and familiar source of worry, perhaps especially in the United States. ${ }^{119}$ The larger debate is obviously beyond the scope of

Supra note 90. The Act's preamble states that "the Supreme Court of Canada has determined that the result of a referendum on the secession of a province from Canada must be free of ambiguity both in terms of the question asked and in terms of the support it achieves ... and that a qualitative evaluation is required to determine whether a clear majority in favour of secession exists." The preamble concludes that "it is incumbent on the Government of Canada not to enter into negotiations that might lead to the secession of a province from Canada, and that could consequently entail the termination of citizenship and other rights that Canadian citizens resident in the province enjoy as full participants in Canada, unless the population of that province has clearly expressed its democratic will that the province secede from Canada."

A speculative example may be helpful to illustrate the courts' role under the Secession Reference and democratic experimentalism. Lower courts would still have the responsibility for ensuring that the animating constitutional principles set out by the Supreme Court of Canada continue to define the field on which any deliberations occur. In the event of dispute the court's role would be to satisfy itself, based on evidence provided by the parties, that participants were observing legitimate deliberative processes and that the substantive goals they advocate do not undermine the deep norms set out by the Supreme Court of Canada. The lower courts could operate in essentially the same way (albeit with different tools) that they do when reviewing the conduct of administrative tribunals for their adherence to standards of due process and natural justice. Because the democratic experimentalist process produces its own measures, reasons, and internal standards, however, courts would have better access to the kind of hard factual evidence that makes for solid judgments. Groups that can establish their ability to abide by legitimate participatory practices, reflect on their own experience, and learn from others' will earn greater deference from the courts. As Dorf and Sabel point out, this sort of rigorous fact-based analysis is exactly what judges are trained to do, and they are particularly well-suited to the role when the general principles at stake are legal ones relating to federal structures, constitutional norms, and the rule of law. Litigation aside, it may also be that the legal profession has a special role to play in democratic experiments of this nature. Professor Sturm argues that by virtue of their training, lawyers are in a unique position to anticipate issues; to link aspirational constitutional norms with actual organizational practice and goals; and to help participants understand and apply those values, familiar to law, of faimess, participation, reasoned decision making, and principled conduct. S. Sturm, "From Gladiators to Problem-Solvers: Connecting Conversations about Women, the Academy, and the Legal Profession" (1997) 4 Duke J. Gender L. \& Pol'y 119.

Most recently see F. Michelman, Brennan and Democracy (Princeton, NJ: Princeton University Press, 2000). I would argue that at least some of the worries that are expressed about democratic experimentalism actually boil down to general worries about democracy, writ large. Some others seem to derive from the fact that democratic experimentalism puts difficult questions about identity 
this article, which restricts itself to the question of democratic experimentalism's compatibility with Canadian history, society, and constitutional values. But Canada has a relatively long history of managing social diversity, cultural pluralism, and official bilingualism. Its experience has also given rise to an exceptionally sophisticated national conversation about identity, rights, and democracy. For these reasons, the Canadian situation makes a unique and valuable contribution to the larger debate taking place in North America, Europe, Westminster, and elsewhere. The position I take is that democratic experimentalist methods can be sensitive to the Canadian tradition of granting explicit recognition to minority groups, as well as individuals, and that there is nothing in the Secession Reference that would contraindicate applying a DE-style fluid deliberative model. On the contrary, the model may hold out substantial promise as a way of managing the tension between group and individual rights in Canada. Moreover, the understanding of constitutional federalism and the "clearqualitative majority" that emerges in the SecessionReferencemakes an important contribution to democratic experimentalism itself. $^{.20}$

\section{EQUALITY AND RESPECT FOR MINORITIES}

In the experimentalist democracy imagined by Dorf and Sabel, proper decision-making bodies are decentralized, fragmented, and fluid organizations, focused on solving discrete problems and reaching pragmatic goals. The assumption is that, apart from creating betterequipped, more effective decision-making bodies, this model increases the circle of democratic participation and multiplies the opportunities available to citizens to act in the public sphere. The further assumption is that such groups would actually come to value diversity in their membership as a means of discovering new options and developing better solutions in their decision making. Two important requirements, however, are that the groups remain fluid and that the interests they represent not become entrenched. The negotiation and deliberation process could not be a log-rolling or pie-dividing endeavour among long-established constituencies. Seen from this perspective, one of the assumptions of democratic experimentalism is that individual liberty is best protected through a process that prevents entrenched groups from having a permanent say in the deliberations.

For the Supreme Court of Canada, by contrast, a proper deliberative process has to take place within a context that expressly respects distinct minorities. It is, frankly, not clear what the Court has in mind by the term "respect for minorities." Whether out of necessity given the difficulty of setting out the contours of the concept or out of deference to the

and social choices squarely on the table in the expectation that they can be more legitimately and effectively dealt with through open democratic deliberation than through less transparent and less explicit or less intentional means.

I do not want to underemphasize this point. In its pure form Ungerian radical democracy seriously underestimates the impact of power dynamics and of the self-reproduction of exclusionary social groups on the emergence of flexible new forms of democracy. To a lesser degree, democratic experimentalism attracts the same criticism. For this reason Canadian-style recognition of group allegiances seems to me to offer an essential, perhaps even indispensable, additional dimension. I agree with Michael Ignatieff, who recently argued that Canada's evolving "civic nationalist" rights culture, which has emerged in the last thirty years as a distinctive product of Canada's multicultural, multilingual history and its national struggle to reconcile unity with diversity, makes a particularly important contribution to rights talk in this regard. M. Ignatieff, The Rights Revolution (Toronto: Anansi, 2000). 
political nature of the constitutional problem, the Court has refused to define its meaning with any specificity. Certainly, we do not know from the text of the judgment what it is to "respect" a minority or even what it is (as the Court expresses the concept elsewhere) to "accommodate"121 or "protect"122 minorities. In its most explicit reference to the actual values it has in mind, the Court refers to the constitutional aim of ensuring that

vulnerable minority groups are endowed with the institutions and rights necessary to maintain and promote their identities against the assimilative pressures of the majority. ${ }^{123}$

We are not told whether those groups attract constitutional protection because they are vulnerable; because historically they were ignored or actively mistreated; because they have collective identities that (for any number of reasons) should be maintained and promoted; because assimilation into the majority of the polis is in itself a bad thing (again for any number of reasons); or simply because all numerical minorities attract some degree of constitutional protection. ${ }^{124}$ The Court's clear focus on cultural and linguistic minorities and the religious, educational, and language rights accorded them in the past suggests a genealogical element to the principle - that either historical disadvantage or perhaps the importance of a particular minority group (such as French Canadians) in historic constitutional negotiations is relevant. Whether other kinds of minorities (for example, minorities as defined by their sexual orientation) are entitled to the same protection does not attract explicit comment. Similarly, there is no reference to the status of women, the poor, or other groups who historically were not accorded the same levels of "respect" in the political process as more privileged groups, but who may not, strictly speaking, be minorities. On the other hand, the fact that the Court steadily refuses to set out who the minorities in question actually are undoubtedly says something important about what it is trying to accomplish. Deciding whether the Supreme Court's understanding of respect for minorities is compatible with democratic experimentalism must, therefore, come down partly to interpretation.

The Secession Reference does embody certain general beliefs about respect for minorities. To begin with, it is clear that the Court does not see an inherent conflict (or at least not an irreconcilable one) between protecting traditional liberal individual rights and the "respect for minorities" principle; references to "individual and minority rights" are sprinkled throughout the Secession Reference. The same linkage demonstrates the Court's desire to articulate this defining constitutional principle in the familiar language of rights. The "principle of minority rights" continues to resonate with the Court in spite of the acknowledged fact that the shape of minority rights in Canada is uncertain and, to the extent known, is the path-dependent product of identifiable past compromises. Moreover, the Court's identification of some broader principle of respect for minorities

Secession Reference, supra note 6 at paras. 44, 48, 64 .

Ibid. at paras. $38,46,79,80$.

Ibid. at para. 74.

The Court's own views on minority protection under the Charter have been set out fairly specifically in the last fifteen years, particularly through litigation under the equality provisions contained in $\mathbf{s}$. 15 of that document. These cases are instructive. However, the Secession Reference discussion focuses on principle, not precedent. It would be very bold to suggest that those Charter precedents had generated a comprehensive and conclusive rule book on how to respect minorities here, in the context of a political discussion, on secession, in Quebec. 
in Canadian constitutionalism suggests that the categories of minorities actually entitled to respect are not limited to those that have already negotiated them or that have been recognized as having them. The Court's view mirrors the "awkward consensus"125 described by Dorf and Sabel in observing that, even though minority rights protections in Canada clearly are the product of historical political compromises, this does not mean that they are "unprincipled." 26 Yet the Court is not engaged in a Hegelian process of "discovering" the innate reason behind the law; nor, as seems clear by its terms, can the Secession Reference be reduced to a positivist list of what rules have acquired the status of rights conventions to be followed for that reason alone. Rather, it seems to be saying that historical provisions for minorities reflect a recognition of an important idea of rights, whose recognition ought to (and whose definition then will have to) continue into the future.

Interestingly, the Court also makes repeated, seemingly offhand reference to cultural and group identities. ${ }^{127}$ Despite the casual form of the commentary, it at least suggests the important point that cultural or group membership is, in some unspecified way, tied into some kind of group identity. In the context of the Secession Reference and the language-based issues in Quebec, however, that identity should not be seen to be tied to an immutable characteristic shared by group members; language, to take the obvious example, is not immutable. Group membership is neither an unshakeable, singular foundation of identity for group members, nor a rigid determinant of the options available in seeking an accommodation with and within the larger group. Cultural or group membership is only one factor in the structure of Canadian constitutionalism; the Supreme Court does not suggest that Canadian citizens can be understood exclusively and conclusively as "members of this family or community or nation or people, as bearers of that history, as citizens of this republic."128 The principle of respect for minorities is not permitted to trump the other fundamental principles of federalism, democracy, and constitutionalism and the rule of law. The goal cannot be to entrench protections of group rights at the expense of those other principles that ensure a multi-forum government structure, an accountable and representative state, the protection of individual rights, and the expression of the sovereign will - or to entrench any of those principles at the expense of the others. Thus the "respect for minorities" principle cannot be boiled down entirely to a recognition that cultural and linguistic associations are crucial elements of identity, although this is definitely part of the mix.

On the other hand, although they are not monolithic, minority groups are seen to be distinct from the polity generally, at least in their broad outlines, and entitled to some level of respect by virtue of that differentness. The political model described by the Court is not so much a pure civic-republican model as it is a model of multicultural citizenship along the lines variously described by Canadian writers like Will Kymlicka, James Tully,

\footnotetext{
125 "DE," supra note 63.

126 Secession Reference, supra note 6 at para. 80.

127 For example, see supra, text accompanying note 103.

128 M.J. Sandel, "The Procedural Republic and the Unencumbered Self" (1984) 12 Political Theory 81 at 86.
} 
and Charles Taylor. ${ }^{129}$ For Taylor, subnational group memberships, including cultural and linguistic associations, are central and abiding components of our largely socially determined identities. As a result, a presumption of equal recognition and respect for such associations is necessary to ensuring full and equal personhood for everyone in the properly functioning democratic polity. ${ }^{130}$ For writers like Kymlicka, one of the reasons that collective rights and cultural survival mechanisms are important is because they affect the substance (and not just the exercise) of individual liberal rights: members of some vulnerable communities will not be able to exercise meaningful choice if they are deprived of the "cultural structures" that give those choices their person-specific content. ${ }^{131}$ In the result, a comprehensive theory of justice in a multicultural state is understood to actually require both universal rights for all and certain group-differentiated rights for minority cultures as a function of full citizenship. ${ }^{132}$

Significantly, the multicultural citizenship model asserts that there is more to protecting minority communities than "leveling the playing field" to ensure that individuals in those groups are not less able to exercise their individual civil rights than members of the majority. It wants to protect those minority communities for their own sake. As the Court does in the Secession Reference, multicultural citizenship models actively invite communities to "promote" their own language and culture. ${ }^{133}$ In employing this model, the Supreme Court of Canada is working from within a model of democratic deliberation that expressly acknowledges the polyethnic, heterogeneous nature of Quebec and Canada,

The term "multicultural citizenship" is Kymlicka's, and on a general level it is a good descriptor. However, I do not mean to suggest that Taylor, Tully, and Kymlicka share a common approach to all aspects of rights and citizenship. Taylor, in particular, places greater emphasis on the sources of personal identity in group membership, and although he expresses admiration for his writing, he does not believe that Kymlicka's ideas necessarily go far enough: C. Taylor, "The Politics of Recognition" in A. Gutmann, ed., Multiculturalism: Examining the Politics of Recognition (Princeton, NJ: Princeton University Press, 1994) [hereinafter "Taylor"]. For his part, Kymlicka has expressed some discomfort with what he sees to be the communitarian strains in Taylor's writing: see, for example, W. Kymlicka, Liberalism, Community and Culture (New York: Clarendon Press, 1989) at 2-3 [hereinafter "Kymlicka"]. See also J. Tully, Strange Multiplicity: Constitutionalism in an Age of Diversity (New York: Cambridge University Press, 1996). My assertion is simply that their views are consistent to the extent described in the paragraph above. Americans and others who also recognize some role for social and/or group recognition in the public deliberative process include Iris Marion Young, Seyla Benhabib, Joshua Cohen, Martha Minow, Yael Tamir, and Jurgen Habermas. Joseph Raz also argues that group rights are often a precondition of individual rights: J. Raz, The Morality of Freedom (New York: Oxford University Press, 1994) at 193-216. John Rawls, himself, has probably moved closer to this perspective in acknowledging the possible existence of "a plurality of reasonable yet incompatible comprehensive doctrines": J. Rawls, Political Liberalism, (New York: Columbia University Press, 1993) at xvi. I am not suggesting that there is a national consensus in either country about what rights mean, nor am I attempting to set up some sort of essential juxtaposition of "Canadian" and "American" perspectives. As noted above, the purpose here is more discrete: this is a preliminary attempt to determine whether a particular theoretical model of democratic deliberation can help to make sense of the Quebec Secession Reference and the democratic process it contemplates, bearing in mind some of the more significant features of Canadian society and constitutionalism.

Taylor, ibid. at 29-36. See also C. Taylor, Sources of the Self: the Making of Modern Identity (Cambridge: Harvard University Press, 1989).

131 Kymlicka, supra note 129 at 165.

132 W. Kymlicka, Multicultural Citizenship: A Liberal Theory of Minority Rights (Oxford: Clarendon Press, 1995) at 6. 
and - here, pulling most clearly away from the civic-republican school - of those groups' relevance to the sphere of public deliberation. And indeed, when addressing the possible secession from Canada of a culturally and linguistically distinct subgroup, it is difficult to imagine how the Court could validly have done anything else.

The assertion that comes out of the Secession Reference is that the democratic process must respect those aspects of minority affiliation that are important to the minority individuals' status as full citizens in the political process. It is significant that the Court has linked together individual and group rights in the Secession Reference and that it has grounded its discussion on the notion of respect. Real civic engagement with the democratic process is essential not only to the protection of individual rights, but also to full personhood because it is only through interaction with others that one's identity as an individual becomes shaped and one's rights acquire content. Political engagement is an important aspect of that public, social, and personal identity. Both the Secession Reference and democratic experimentalism refer repeatedly to notions of "selfgovernment" and "self-determination" as crucial elements of true democracy - but in this context, self-determination means not only giving a group the social, public, and cognitive space to create its own future, but it also means giving it the space to define for itself what it essentially is in the present and in the context of the problem to be solved. ${ }^{134}$ Public and equal recognition of a group's self-defined essential elements, along the very axes in which they matter (for example, recognizing language rights in contexts like public education) is the essence of respect and of full and meaningful participation in a rich democratic process. ${ }^{135}$ Yet those group characteristics must struggle to coexist with individual rights, the rule of law, and the spirit of open and respectful democratic deliberation. ${ }^{136}$

"Self-determination" in this context is not a term of art as it is used in international law. See, for example, H. Hannum, Autonomy, Sovereignty, and Self-Determination: the Accommodation of Conflicting Rights (Philadelphia: University of Pennsylvania Press, 1990) at 44.

The concept of equal respect as the unifying force between notions of equality and liberty derives from J.H. Ely, Democracy and Distrust: A Theory of Judicial Review (Cambridge: Harvard University Press, 1980).

The related question of how a liberal democracy ought to deal with illiberal values or practices on the part of minority groups in its midst has attracted a great deal of attention. An interesting recent approach to squaring a commitment to substantial liberal values with a recognition of cultural pluralism has been put forward by A. Bilgrami, "The Philosophy of Rights and Cultural Identity" (School of International and Public Affairs Lecture, Columbia University, 3 November 1999) [unpublished]. He argues that liberal doctrine should not retreat to founding its doctrine on some minimal shared ground that even illiberal particularisms might share. It can insist on the full and substantial liberalism it is committed to, while at the same time holding out the hope that illiberal elements in various communities within its citizenry might be brought around to these full substantive liberal commitments by giving them arguments that appeal to values within the other commitments of those communities. Consistent with my position here, Bilgrami presupposes that as a matter of empirical fact, there is always room to find some internal tension (or potential tension), even within those who hold illiberal commitments. Thus pluralistic liberalism on this view does not mean that illiberal practices must inevitably be tolerated. It also does not mean that liberals should follow the traditional approach of simply making a priori arguments that all "rational people" are somehow bound to accept. Rather, it means that liberals may strive to bring others around to liberal practices by giving arguments that might be very different in each case, thereby appealing to different internal tensions in different illiberal communities. To this comment I would add that the process is a dialogue, and it is always open to minority communities to counter an insistent liberal position with further arguments, including arguments based on liberalism's own commitments to equal respect. 
Returning to democratic experimentalism, one recalls Dorf and Sabel's condition that social roles, groups, and hierarchies not become entrenched so that the democratic process can operate effectively. Disentrenching stable social groups does not mean denying that group membership matters to individual identity, democracy, or justice. I do not read Dorf and Sabel to be suggesting that deeply deliberative democracy requires individuals to bargain away central, socially-derived constituents of their identities; on the contrary, they recognize the relationship between rights and both individual and group identity. Nor are they claiming that individuals are infinitely mutable, free-floating units without unique perspectives that derive from their own lived experiences and social ties. If this were the claim, then diversity and broad, intersectoral participation would not be the valued and central parts of the democratic experimentalism model that they are. Moreover, democratic experimentalism does not suggest that group affiliations are not meaningful social constructs. The model is concerned with reducing exclusion and increasing social connection to a deeply representative and democratic process. No model can operate with these goals without noticing the ways in which membership in particular groups affects the opportunities, expectations, self-understanding, and perceived capacities of its members. To pretend that group-based stereotypes, on one hand, and tightly knit community networks, on the other, do not matter to individuals' connection to public deliberation is not reasonable, and it is not consistent with DE. In truth, rigidly denying the relevance of social groups and roles would be as inconsistent with democratic experimentalism as actually entrenching groups would be because both positions arbitrarily limit the range of possibilities that can be imagined for realizing social goals.

What democratic experimentalism contests is the notion that stable social groups should be permitted to entrench their roles in the deliberations, to hoard authority and limit others' access to the forum, to foreclose internal debate or external challenge, and to insulate themselves from change. Democratic experimentalism questions the ability of any group legitimately to speak for all of its members, on every issue, across time and space. It denies that there can be any unshakeable group-based "way to be" that can prescribe and predict individual potential in every respect. It denies that all public conversations between groups set up in opposition to each other have predetermined results, that there is never any room to move. Democratic experimentalism recognizes that important group identities, while they are entitled to space and respect, are nonetheless complicated and contestable. ${ }^{137}$ Recognizing the integral elements of individual and group identity is an important task for any society. Imagining ways to square group membership with belonging to a larger community is important not only to individual identity, but also to developing common goals that can improve the lot of each. Democratic experimentalism asserts that defining and reaching those common goals is best achieved through continuous at 34-46, who has commented on the tendency, in group-based analysis, to reduce complex individuals to one identifying trait and then to imagine that they can be described for all purposes along that axis. There is also the related tendency to neglect intersectionality - the fact that all individuals are members of multiple groups to some degree - and there are problems with what Professor Minow calls group "boundaries, coherence, and content." She points out that real-world group identities are blurry, fluid and contestable; to describe them otherwise is to do violence to the full personhood of its members. On the problem of essentialism, see also A. Harris, "Race and Essentialism in Feminist Legal Theory" (1990) 42 Stan. L. Rev. 581. 
and respectful democratic deliberation, which recognizes both individual and group rights - and provides mechanisms for keeping those constructs moving and fluid.

When seen in these terms, there are large and useful zones of compatibility between the democratic experimentalist model and multicultural notions of citizenship. Significantly, both are informed by the belief that individual citizens contain within themselves overlapping and sometimes conflicting layers of identity and allegiance,several of which may be entitled to respect and recognition at once. Thus one can be simultaneously an individual, a lawyer, a francophone, a mother, a Montrealer, and an Indo-Canadian. ${ }^{138}$ Each of those shorthand labels is likely, to varying degrees, to be significant to one's identity and deserving of respect; however, they will almost certainly never sum up to a perfectly consistent and predictable political decision-making unit on every issue. Nor should such imagined integrity be imposed; political decision-making structures should not be designed to force citizens to represent themselves in unidimensional, essentialized terms. In addition, multicultural citizenship models and democratic experimentalism both imagine true democracy as a continuous process of debate, negotiation, and collaboration through which goals are defined and problems are addressed pragmatically, within a general framework of rights and rules but without reference to fixed first principles. Both recognize that rights are central to political identity, and both accord moral weight to the reciprocal relationship between rights (including recognition) and identity, in spite of the path-dependent quality of any particular articulation of those rights. In addition, both value rather than discourage diversity within the polity, not only for its ability to bring new perspectives to the decision-making forum but also in its own right on personal, social, and public levels. Thus, I argue, both democratic experimentalism and multicultural citizenship theory hold in common the principles of democracy, respect for minorities, and individual rights protection (embedded in the idea of constitutionalism and the rule of law), described as the animating constitutional principles of Canada.

The Secession Reference also describes federalism as a pillar of Canadian constitutionalism and the "lodestar by which the courts have been guided" from the beginning of Confederation. ${ }^{139}$ The definition of federalism developed in the Secession Reference represents a careful response to the demands of Canadian diversity and multicultural citizenship, as a structure that allows citizens to express themselves as individuals in a variety of different collectivities, accompanied by a public declaration of respect for minorities that makes space for expressing important group-based commitments. The result is an approach to democratic experimentalist governance that actively seeks to recognize social pluralism and that admits of a more complicated understanding of both collective and personal sources of individual identity. Dorf and Sabel point out that in order to be representative, a democracy should be based on flexible, overlapping, negotiable decision-making units that reflect the shifting nature of personal identity, and political commitments. On this level, then, Canadian federalism is a model that is equipped to create, within a diverse and dynamic society, the kind of Nationalism Without Walls: The Unbearable Lightness of Being Canadian (Toronto: MoClelland \& Stewart, 1995). 
responsive and inclusive constitutional process to which democratic experimentalism aspires. $^{140}$

One important caveat exists: within the larger project, special thought would have to be given to Aboriginal peoples and the province's northern regions. Geographic isolation, small and culturally relatively homogenous communities, potential cynicism about the usefulness of "white" or "southern" methods, and the longstanding socio-economic marginalization of many northern communities will generate a host of special concerns in those regions. Compounding this is the fact that First Nations communities have strong reasons to remain part of Canada, ${ }^{141}$ given the federal government's historical fiduciary duty toward First Nations and, arguably, their concerns about the extent to which an independent Quebec would assume those responsibilities. In moral, historical, and legal terms, the position of Aboriginal nations vis-a-vis the Crown is undeniably different, and that difference must be taken seriously. Emphatically, the Aboriginal perspective on an independent Quebec must be given due regard, and the democratic experiment may be expected to take a rather different path in Quebec's northern regions; however, this is not a reason to assume that this deliberative project cannot or need not operate there. Difficult and complex problems are best approached through smaller, concrete steps, and comfort and facility can increase through experience. Flexible and democratic deliberative methods can be useful tools for moving the public debate forward, in the north as elsewhere.

More optimistically, it should be remembered that Aboriginal peoples do not stand only to lose through democratic experimentation. Problems of geography, access, and resources are not insoluble. In fact, Aboriginal peoples' geographic concentration in regions such as Nord-du-Quebec and Côte Nord may have a positive aspect, in that the Aboriginal perspective will very much guide local deliberations taking place in those regions. This situation echoes one of the advantages that the Supreme Court of Canada perceives to flow from federalism, that of ensuring identifiable minority communities gain access to adequate representation by forming majorities at a more local level. Aboriginal experience

In fact, integrating democratic experimentalism with federalism on the multicultural model - that is, with federalism used as a means of dealing with pluralism - brings out a further set of synergies between the two. The topic is the subject of another paper entitled "Flexibility Good and Bad: Directions and Disagreements for Canadian Federalism" [unpublished] in which I argue that federalism continues to provide the best model for managing cultural pluralism in Canada, fascinating new constructions of "network governance" and other post-statist theories notwithstanding.

The Aboriginal peoples of Quebec are divided into 10 nations and 41 communities including the Cree, Mohawk, Huron and Montagnais and Attikamek, in addition to the Inuit from Ungava and the Innu from Labrador. The tone of their response to the referendum process differs according to whether they are French or English-speaking. However, many are strongly opposed to an independent Quebec and the Cree in particular consider secession an illegal violation of native rights. The Cree, Inuit, and Innu peoples held their own referendums on secession on October 27, 1995, on the question of whether they wanted their people and traditional territory to be associated with an eventual independent Quebec. The votes respectively were 96 percent, 95 percent and 99 percent against. The positions of the Grand Council of the Crees and the Innu are set out on their nations' web sites, online: Grande Council of the Crees <http://www.gcc.ca/ PoliticalIssues/secession/secession.htm> (date accessed: 13 August 2001); "Déclaration des Innu sur la Séparation du Québec, online: Innu Nation <http://www.innu.ca/sepyqb1.html> (date accessed: 13 August 2001). Mativik, the organization representing the Inuit people of Nunavik at the time of the referendum, no longer posts their pre-1996 press releases online; however they are available on the uni.ca homepage, online: <http:/www.uni.ca/makivik_prs.html> (date accessed: 25 August 2001). 
with more consensual forms of social decision making, and with thinking about novel kinds of self-determination may also make Aboriginal peoples particularly valuable contributors to the province-wide debate. Particularly, combined with the ongoing negotiations between Quebec, Canada, and Aboriginal peoples about self-determination, it may even be that having access to this kind of participatory and responsive process will go some distance toward renewing those peoples' faith in the political process. Perhaps most importantly, a well-functioning experimentalist process may throw up wholly new ideas, more satisfactory than the status quo to all concerned, about how to structure Aboriginal peoples' relationships with Quebec and Canada. ${ }^{142}$

\section{Conclusion: The Qualitative Clear Majority}

This article represents a first attempt at consciously marrying direct democratic deliberation with the enforcement of important constitutional norms, in the context of a real-life policy question and across the boundaries of national legal traditions. It is an ambitious goal. However, the exercise of thinking about it is worthwhile for a number of reasons.

The most obvious reason for entertaining a new approach is that Canadian federalism is troubled and may benefit from the injection of fresh ideas. Constitutional problems are not only the stuff of ivory tower debate; in profound and pervasive ways they affect the shape of our public spaces, our societies, and our public conversation. Unresolved antagonisms and the apparent inevitability of unsatisfactory arrangements take a toll on public confidence and social resilience, bleeding energy and resources from other productive spheres of activity. The upside is that used well, constitutional structures are the working link between the challenges of real-world governance and a society's deepest aspirational ideals. Healthy societies need to take their national constitutional structures seriously and explore all the options available to them. Thus even if non-Canadian

The Court's discussion of Aboriginal peoples in the Secession Reference is vague indeed, although it emphasizes the importance of Canada's obligation to Aboriginal peoples. It is possible that that obligation may be understood in terms other than that of a fiduciary relationship between Canada and Aboriginal peoples. In conversation on November 9, 1999, Professor Sabel raised the interesting possibility that the idea of a fiduciary relationship is a "prophylactic rule," or in DE parlance, it is an example of courts setting minimum, general preventive standards to give effect to deeply established but vague constitutional norms. When seen in these terms, the fiduciary construct is only one historically-contingent and negotiable means of recognizing Canada's special relationship with its First Nations peoples. It is open to the polity, through democratic and responsible means, to come up with other options for meeting the same obligations. Those options may include, for example, various incarnations of self-government along the lines pursued in British Columbia with the Nisga'a Nation and others. The terms of the Secession Reference would probably require negotiations between Canada, Quebec, and the Aboriginal nations in question in this context as well. The suggestion is reminiscent of Kirsty Gover's and Natalie Baird's observations about the New Zealand situation, supra note 18, and in fact traces of a more negotiable, open-ended Crown/First Nations relationship may already be at play in the narrower context of the "duty to consult" in Canada: see S. Lawrence \& P. Macklem, "From Consultation to Reconciliation: Aboriginal Rights and the Crown's Duty to Consult" (2000) 79 Can. Bar Rev. 252. 
constitutional models may seem unlikely sources of inspiration, other perspectives ought to receive honest and careful consideration before being rejected out of hand. ${ }^{143}$

Second, Canada has a unique contribution to make to the transnational conversations about governance that are taking place. Its experience in applying new public management models in a variety of public and social contexts is an important component of Westminster and North American understandings of public sector reform. More profoundly, Canada's experience with democracy, cultural pluralism, and social compromise is rich and relatively long. That history has given rise to a sophisticated national body of thought that can offer substantial refinements to what I argue are essentially compatible new governance models being developed elsewhere. Moreover, the Secession Reference itself may raise the bar for democratic constitutionalism. One of the basic characteristics of modern constitutions is that they may not be amended by simple majority vote. In this context, the Supreme Court's notion of the "clear qualitative majority" agreement, infused with the principles of federalism, democracy, constitutionalism and the rule of law, and respect for minorities, represents an innovative definition of the more-than-simple-majority that runs along substantive, as well as numerical, axes. The "clear qualitative majority" suggests a democratic process with a moral claim to legitimacy that extends beyond any particular issue and beyond Canada's own experiences with constitutional decision making.

Third, it is not the least virtue of democratic experimentalism that it puts hard questions about democracy and constitutionalism firmly and explicitly on the table. The model is valuable in the Quebec context because, without downplaying the magnitude of the issues, it imagines law as a positive tool for creative, collective action. For Quebec, the secession debate is one manifestation of larger questions about identity and aspirations that it (at least as much as every other nation) faces in a globalizing and ever more complicated world. These are political, social, moral, and literally "constitutional" questions - not just legal ones. Democratic experimentalism represents an organized, conscious, democratic and yet essentially pragmatic approach to them. It is an attempt to engage all the public, civic, and cognitive resources the society possesses in the service of responding to those questions. Moreover, it sees citizens as subjects, not objects, capable of imagining and building a more fulfilling and effective public life. If a consensus cannot be reached through a process as legitimate and accountable as this one tries to be (or as this one can be as modified by its own continuous institutional learning) then one may be hard pressed to blame the process.

Sujit Choudhry makes a compelling argument for comparative jurisprudence in constitutional interpretation in S. Choudhry, "Globalization in Search of Justification: Toward a Theory of Comparative Constitutional Interpretation" (1999) 74 Ind. L.J. 819. He reviews theoretical models and the actual interpretive methodologies and normative justifications used by courts in several countries (including the United States, South Africa, and Canada) in the process of judicial review. He also considers the strengths and weaknesses of each of the three models he identifies: the universalist, the genealogical, and the dialogical. Incidentally, his review of Canadian cases on Aboriginal rights leads him to conclude that the Canadian method is primarily genealogical. I would argue that the methodology of the Secession Reference (which he does not consider) is at least as accurately described as dialogical. 
The truth is that there are no guarantees that a clear qualitative majority would emerge from a true democratic experiment in Quebec. The ultimate outcome may be that the province will discover its identity to be a messy one that resists being fenced in by tidy, "clear questions."144 The advantage to the piecemeal method proposed here is that it ought to be possible nevertheless to identify a core of shared values that can be reflected in Quebec's relationship to the rest of Canada, without having to corral the entire range of public sentiment on every issue. While substantial and continuing disagreement within Quebec is a less than utopian outcome, it would not mean that the process had failed. A respectful deliberative process has value in itself. Moreover, federal democratic structures are designed expressly to accommodate messy, volatile identities on an ongoing basis. In the end, the experiment imagined at the beginning of this article may boil down to an exercise in understanding just that.

The Secession Reference rightly draws on Canada's rich constitutional traditions of democracy, federalism, the rule of law, and the protection of minorities in thinking about Quebec's relationship to the rest of the country. To this we might add the Canadian history of compromise and a desire for peace, order, and good government. In the end, however, both constitutional principles and theoretical constitutional models are of limited value if they do not have the opportunity to play themselves out in the real world. If Canada's constitutional qualities are to be anything more than aspirational, Quebec's secession debate will require something more than a winner-take-all, yes/no vote on a question determined by elected representatives. 